DIW BERLIN

Discussion

Papers
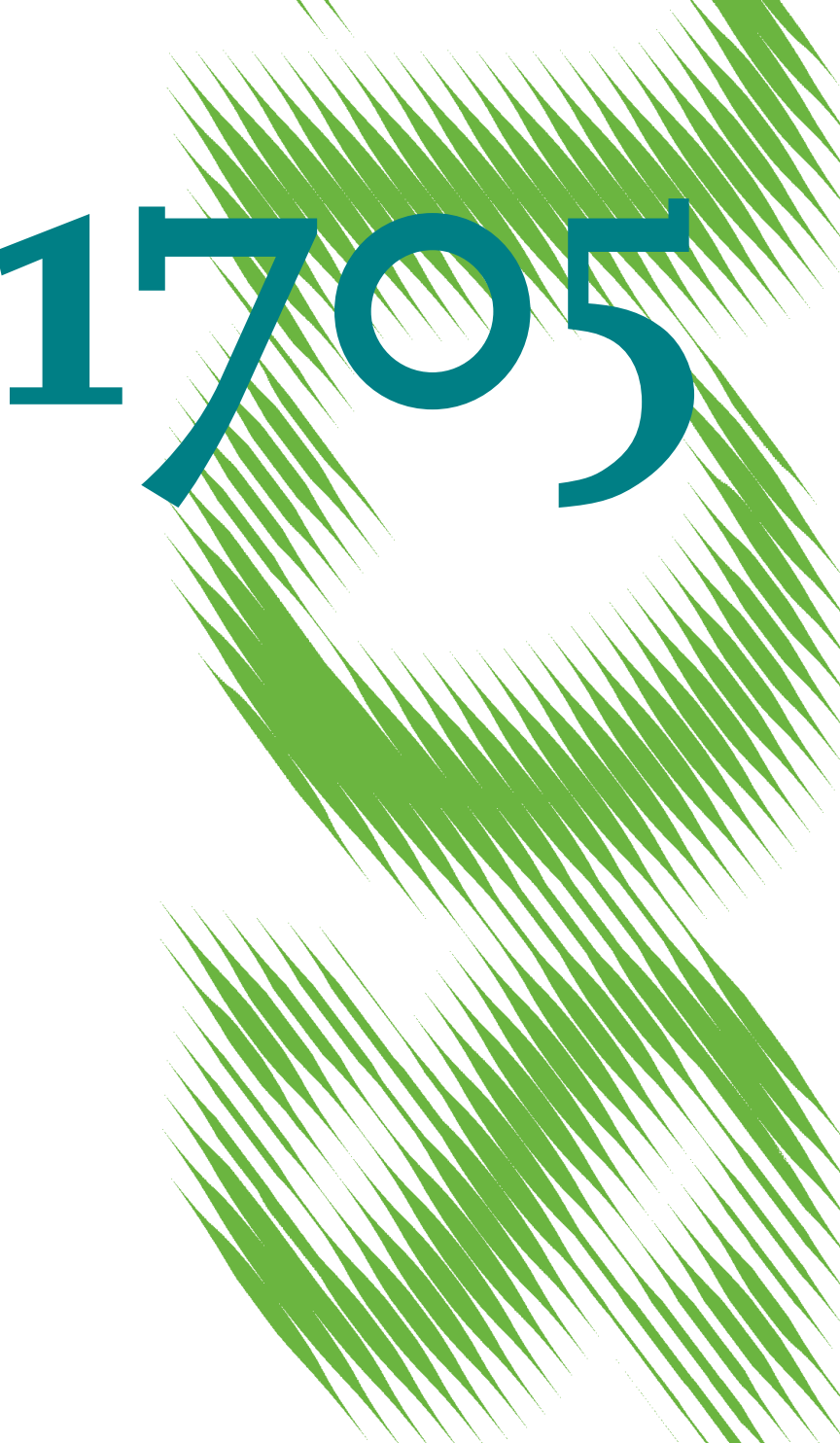

MIMMMMMMMM

Patrilocal Residence and Female Labour Supply 
Opinions expressed in this paper are those of the author(s) and do not necessarily reflect views of the institute.

IMPRESSUM

(C) DIW Berlin, 2017

DIW Berlin

German Institute for Economic Research

Mohrenstr. 58

10117 Berlin

Tel. +49 (30) $89789-0$

Fax +49 (30) $89789-200$

http://www.diw.de

ISSN electronic edition 1619-4535

Papers can be downloaded free of charge from the DIW Berlin website:

http://www.diw.de/discussionpapers

Discussion Papers of DIW Berlin are indexed in RePEc and SSRN:

http://ideas.repec.org/s/diw/diwwpp.html

http://www.ssrn.com/link/DIW-Berlin-German-Inst-Econ-Res.html 


\title{
Patrilocal Residence and Female Labour Supply
}

\author{
Andreas Landmann* \\ Paris School of Economics, J-PAL Europe and C4ED \\ Helke Seitz ${ }^{\dagger}$ \\ German Institute for Economic Research (DIW Berlin) \\ Susan Steiner ${ }^{\ddagger}$ \\ Leibniz Universität Hannover and IZA
}

December 4, 2017

\begin{abstract}
Many people around the world live in patrilocal societies. Patrilocality prescribes that women move in with their husbands' parents, relieve their in-laws from housework, and care for them in old age. This arrangement is likely to have labour market consequences, in particular for the women. We study the effect of co-residence on female labour supply in Kyrgyzstan, a strongly patrilocal setting. We account for the endogeneity of co-residence by exploiting the tradition that youngest sons usually live with their parents. In both OLS and IV estimations, the effect of co-residence on female labour supply is negative and insignificant. This is in contrast to previous studies, which found positive effects in less patrilocal settings. We go beyond earlier work by investigating effect channels. In Kyrgyzstan, co-residing women invest more time in elder care than women who do not co-reside and they do not receive parental support in child care or housework.
\end{abstract}

Keywords: Family Structure, Co-residence, Labour Supply, Patrilocality, Kyrgyzstan JEL codes: J12, J21

*e-mail: alandmann@povertyactionlab.org

$\dagger$ e-mail: hseitz@diw.de

${ }^{\ddagger}$ e-mail: steiner@ifgb. uni-hannover.de. Corresponding address: Institute for Development and Agricultural Economics Leibniz Universität Hannover, Königsworther Platz 1, 30167 Hannover, Germany, Tel: +49511762 3231. Fax: +49511762 2667. 


\section{Funding}

This work was supported by the UK Department for International Development (DFID) and the Institute for the Study of Labor (IZA). It is an output of the project "Gender and Employment in Central Asia - Evidence from Panel Data". The views expressed are not necessarily those of DFID or IZA. We gratefully acknowledge the financial support received. Andreas Landmann received additional funding from project LA 3936/1-1 of the German Research Foundation (DFG).

\section{Acknowledgements}

We thank Kathryn Anderson, Charles M. Becker, Marc Gurgand, Kristin Kleinjans, Patrick Puhani and participants of conferences in Bishkek, Chicago, Dresden and Göttingen for helpful and valuable comments. Many thanks in particular to Damir Esenaliev and Tilman Brück for their support. 


\section{Introduction}

Post-marital residence rules determine where newly wed couples should reside. A large share of the world population lives in societies with a patrilocal residence rule.$^{1}$ This rule prescribes that women move in with their husbands' parents, or sometimes the husband's wider family, upon marriage. When joining the new household, women are usually expected to relieve their in-laws from housework and to care for them in old age (Grogan, 2013, Ebenstein, 2014). Such co-residence arrangements may have significant labour market consequences for the involved women. In this study, we therefore investigate how intergenerational co-residence affects female labour supply in a patrilocal setting. We focus on Kyrgyzstan where elderly parents traditionally reside with their youngest son and his wife.

A priori, the impact of intergenerational co-residence on the labour supply of women is unclear because several channels can be at play and might counteract each other. The literature has elaborated on four channels through which the impact can principally work. First, co-residing parents or in-laws might contribute to household income or share housing and other assets (Maurer-Fazio et al., 2011). Any advantage in economic conditions (e.g. high non-labour income) is likely to make women reduce their labour supply. Second, co-residing parents or in-laws might require care. Women are typically the caregivers in the household. This responsibility increases their value of non-market time (their reservation wage) and reduces their labour supply (Lilly et al., 2007). Third, co-residing parents or in-laws might take care of women's children or take over housekeeping tasks. The reservation wage is reduced for the women, leading to an increase in labour supply (Compton and Pollak, 2014; García-Morán and Kuehn, 2017, Posadas and Vidal-Fernández, 2013; Shen et al., 2016). Fourth, co-residing parents or in-laws might be better able to impose their preferences on a woman's labour market behaviour than distant parents or

\footnotetext{
${ }^{1} 74$ percent of societies around the world were traditionally patrilocal (Murdock, 1967, cited in Baker and Jacobsen, 2007). Today, patrilocality is most common in the Caucasus, Central Asia, and South Asia. The share of elderly co-residing with a son and his wife is particularly high in these societies (Grogan, 2013 : Ebenstein, 2014).
} 
in-laws (Chu et al. 2014$)$. Depending on the type of preferences, parents or in-laws can either induce an increase or a reduction in female labour supply. These four channels are plausible in patrilocal societies in the same way as in other societies - with one exception. Women who move in with their in-laws are assumed to take over housekeeping tasks from them rather than the in-laws taking care of housekeeping for the women (Grogan, 2013). This distribution of tasks within the household should result in more adverse effects of co-residence on female labour supply in a patrilocal context than in a non-patrilocal context.

A simple cross-country analysis illustrates that patrilocal countries are different from non-patrilocal countries. Figure 1 shows the correlation between female labour force participation and intergenerational co-residence rates in patrilocal countries and non-patrilocal countries separately $\left.\right|^{2}$ While co-residence is positively related to female labour force participation in the latter, the correlation is negative in patrilocal countries. This pattern suggests that the effect of intergenerational co-residence is distinct, and potentially negative, in patrilocal countries. Yet, cross-country analysis can hardly provide causal insights. Instead, micro-level investigations are needed.

\section{[INSERT Figure 1 about HeRe]}

There are only few micro-level studies on labour supply effects of living with the parent generation (Kolodinsky and Shirey, 2000; Sasaki, 2002, Oishi and Oshio, 2006.

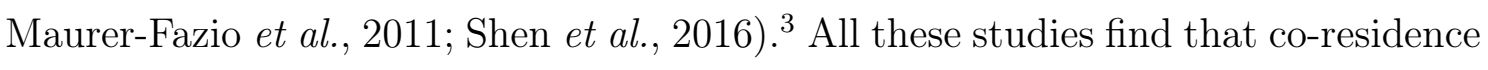
increases female labour supply and claim that this is due to parental assistance with child care and housekeeping. Yet, most of the authors limit themselves to speculation; only Shen et al. (2016) explicitly test and confirm this claim for the case of housework. None of the other channels are analyzed.

In this study, we contribute to the literature by investigating all channels through

\footnotetext{
${ }^{2}$ The list of countries used for this analysis can be found in Table A.1

${ }^{3}$ Additionally, Compton (2015) evaluates the effect of proximity to parents on labour market outcomes of women. She finds that, when controlling for the endogeneity of distance to the parents, close proximity to parents increases the labour force participation of married women. Please note that this study is not fully comparable to the other studies, as it focuses on proximity to parents rather than co-residence with parents.
} 
which intergenerational co-residence can potentially affect women's supply of labour to the market. We focus on Kyrgyzstan, which is a post-Soviet country in Central Asia with a population of 5.9 million and where patrilocality is common: 46 percent of married females in the age group 15-30 live with at least one parent-in-law and only 9 percent live with at least one own parent (Grogan, 2013). Young married women reportedly have the lowest status in their in-laws' household (Kuehnast, 2004). They are supposed to be obedient and to fulfill the demands of their husbands and his parents. Married couples tend to live with the husband's parents until the husband's younger brothers get married. At that point, they often move out and form their own household. According to tradition, the youngest son and his wife never move out and are responsible for the well-being of the parents (Bauer et al., 1997; Kuehnast, 2004 Thieme, 2014; Rubinov, 2014). As a way of compensation, the youngest son inherits the house and the land upon the death of his father. $4^{4}$

In contrast to the previous literature, we do not only measure the impact of living with the parent generation on female labour supply; we also shed light on the channels. With the help of time use data, we can draw conclusions on how time spent on child care, elder care and housekeeping differs between women who co-reside and women who do not co-reside. Furthermore, we have information on income contributed to the household by co-residing parents as well as their attitudes on gender roles. We correlate this information with female labour supply.

Empirical analysis is not straightforward because co-residence is not exogenous. Even in patrilocal societies such as Kyrgyzstan, there is selection into co-residence. Couples that are expected to co-reside with the husband's parents do not always do so, while couples that are not necessarily expected to co-reside sometimes decide to live with the older generation. The reason is that co-residence and labour supply decisions are often made jointly (Sasaki, 2002). For example, young women with low ambition to work outside the home or with conservative attitudes on gender roles may be inclined to co-reside with their in-laws. Additionally, parents are likely to

\footnotetext{
${ }^{4}$ All children traditionally get a share of the parents' wealth, though in different forms and at different times in their life cycle (Giovarelli et al., 2001).
} 
move in with their adult children when they need to be taken care of or when the adult children need them as caregivers for their own children, especially if formal care is not easily available or too costly. If there are several siblings, the co-residence decision could be the result of a bargaining process. The sibling with the lowest (highest) opportunity costs may be the one who co-resides with parents if elder (child) care is required (Ettner, 1996; Ma and Wen, 2016). Due to this endogeneity of co-residence, simple comparisons of co-residing and non-co-residing women are most likely subject to a bias.

To address the endogeneity of co-residence, we make use of the tradition that youngest sons are expected to live with their parents in Kyrgyzstan. This tradition is followed by all ethnic groups residing in the country. It generates exogenous variation in the co-residence of women with the parent generation, driven by the birth order of husbands. We use being married to the youngest son to construct an instrument for women's intergenerational co-residence. We show that wives of youngest sons are significantly and substantially more likely to co-reside than otherwise comparable wives of older sons. Several tests suggest plausibility of the instrument: Youngest sons do not seem to differ from older sons with regard to pre-marriage characteristics and divorce rates. The same holds for their wives.

We find that the patrilocal setting in Kyrgyzstan is different from the settings investigated in the previous literature, as reflected in the deviating overall effect of co-residence on female labour supply. In Kyrgyzstan, co-residence does not significantly affect the labour market outcomes of married females. Effects are negative and insignificant both when using OLS with a large set of control variables and when using an instrumental variable strategy. We find no evidence of parental support to married women. Co-residing women do not differ significantly from women who do not co-reside in terms of time spent on housekeeping and child care. At the same time, co-residing women spend significantly more time on elder care. Income contributed by co-residing parents and their gender attitudes do not seem to be related with women's labour market outcomes. 


\section{Background: Female Labour Supply in Kyrgyzstan}

Despite the political objective of the Soviet government to achieve gender equality on the labour market, the labour force participation rate of females (aged 15-64 years) always remained lower than that of males in what is today Kyrgyzstan. Just before the dissolution of the Soviet Union, female labour force participation amounted to 58 percent in 1990, compared with 74 percent for males (Figure 2). Since then, the distance between females and males has increased: while 50 percent of females participated in the labour force in 2016, 77 percent of males did so.

\section{[Insert Figure 2 about here]}

The provision of institutionalised care for children and the elderly remains low, which potentially keeps women from participating in the labour market. The enrolment rate in formal child care for children aged 3-6 years was as low as 31 percent in 1990, further decreased to 9 percent in 1998 (Giddings et al. 2007) and then increased again to 22 percent in 2013/14 (UNICEF, 2017). The Ministry of Labour and Social Development (2017) currently reports a total of six care homes for the elderly, with 750 residents and an additional 10,000 people receiving care from these homes in their own houses. Compared with around 550,000 pensioners in the country, these numbers are very low. Kyrgyzstani women have been and still are the main providers of care for the household (Akiner, 1997; Paci et al., 2002).

Women tend to be employed in sectors with relatively low pay. The share of females is highest in health care and social services, education, and hotels and restaurant services. The higher paid transportation and communication sector as well as public administration are in turn male-dominated (Ibraeva et al., 2011, SchweglerRohmeis et al. 2013). A sizable gender earnings gap is the consequence. In 2013, men earned approximately 26 percent more per month than women, but they also worked 6 percent more hours. The average hourly earnings gap was 25 percent Anderson et al., 2015). 


\section{Data}

We use data from the Life in Kyrgyzstan (LIK) survey, which is a nationally representative panel, conducted annually between 2010 and 2013 and again in 2016.5 The LIK provides a wide range of individual and household level information on socio-demographic characteristics, employment, and many other topics. In contrast to household panels where only one member of the household is interviewed, the LIK is an individual panel, in which all adult individuals living in the originally sampled households are interviewed and tracked over time. The first wave of the survey included 8,160 adults living in 3,000 households.

In our empirical analysis, we use data from the 2011 wave of the LIK and restrict the estimation sample to married women in the age range 20-50. There are 2,043 such women. We further restrict the sample to those women with at least one living parent-in-law because women without any living parent-in-law do not have the opportunity to co-reside. The 2011 wave did not contain information on whether women's in-laws were still alive. We thus collected supplementary data in 2014 . We obtained information on whether the parents of the LIK respondents were alive in 2011 and on the birth order of the respondents and their siblings. 1,582 women (and their husbands) were successfully re-interviewed in 2014. ${ }^{6}$ Our final sample is further reduced to 1,048 observations due to the following reasons: both parents of the husband are deceased (478 observations), the birth order of the husband could not clearly be identified (1 observation), and there are missing values on the variables used in the empirical analysis (55 observations).

\section{Outcome Variables}

We measure the labour market outcomes of women in two ways: first, the probability to engage in the labour market, i.e. labour force participation (extensive margin),

\footnotetext{
${ }^{5}$ The first three waves were collected by the German Institute of Economic Research, the fourth wave by the Stockholm International Peace Research Institute, and the fifth wave by the Leibniz Institute of Vegetable and Ornamental Crops. For detailed information on the survey, see Brück et al. (2014).

${ }^{6}$ Failure to re-interview was higher in urban than in rural areas.
} 
and second, the number of weekly working hours (intensive margin). Women participate in the labour force if they actively engage in the labour market by working or if they are unemployed and seeking work. In contrast, women do not participate in the labour force if they do not work and do not seek work. In the LIK, engaging in the labour market is measured by (a) working for someone who is not a household member, (b) working for a farm or business owned or rented by the respondent or another household member, (c) engaging in farming, fishing, gathering fruits or other products or $(\mathrm{d})$ being absent from a job to which one will return 7 Women are identified as unemployed if they do not fall under any of these four categories but report that they look for work. For all working women, we observe the number of working hours. We use the total number of working hours per week in our analysis, which may be spent in up to two occupations. ${ }^{8}$ Unemployed women and women who do not participate in the labour force are assumed to have zero working hours.

Table 1 illustrates that close to half of the sample participates in the labour force. Out of 1,048 women, 500 (48 percent) participate in the labour force and 548 (52 percent) do not. Among those participating, 483 are employed and 17 are unemployed. The average number of weekly working hours for employed women is 36 hours.

\section{[INSERT TABLE 1 ABOUt HeRE]}

\section{Co-residence and Youngest Son}

Our main explanatory variable is co-residence. We define co-residence as a married woman - and her husband and children (if any) - living in one household with at least one parent. In principle, the parent can be a parent of the wife or the husband. Out of 1,048 women, 547 (52 percent) live in nuclear families and 501 (48

\footnotetext{
${ }^{7}$ Categories (a), (b) and (d) are defined in accordance with the Integrated Sample Household Budget and Labour Survey of the National Statistics Committee of the Kyrgyz Republic. Category (c) was added in the LIK because the other three categories missed an important part of self-employment activities. The resulting definition of labour force participation conforms to that of the International Labour Organization.

${ }^{8} 1.7$ percent of the women in our estimation sample have two occupations, which corresponds to 3.7 percent of all those with positive working hours.
} 
percent) co-reside with parents or parents-in-law (Table 1). Among the co-residing women, 490 (98 percent) live with at least one of the husband's parents and 11 (2 percent) with at least one own parent. $9^{9}$ These numbers illustrate the extent of patrilocality in Kyrgyzstan. Table 1 shows that women who co-reside tend to supply less labour to the market. 39 percent of co-residing women and 56 percent of nonco-residing women participate in the labour market. Among employed women, coresiding women work 35 hours per week and non-co-residing women work 36 hours (difference insignificant). Co-residence is likely endogenous. We create an indicator variable for whether a woman's husband is the youngest son in his family and use this as our instrument for co-residence. 35 percent of the women in our sample are married to a youngest son. Co-residence and marriage with a youngest son are strongly associated: Among the co-residing women, 50 percent are married to a youngest son; among the non-co-residing women, only 21 percent are married to a youngest son (Table 1).

\section{Other Covariates}

In addition to co-residence, several other factors potentially drive labour market outcomes of females. We here describe the variables that we use as controls in our analysis (descriptive statistics are reported in Table A.2 in the Appendix). Note that we restrict ourselves to variables which are plausibly unaffected by individual co-residence decisions to avoid problems of endogenous controls.

Our first set of variables characterizes the woman. Following Mincer (1958), we include her educational attainment (dummies for different stages of education: low, medium, and high) and age (as a proxy for experience). Kyrgyzstan is a multi-ethnic society with ethnicity-specific gender norms related to the labour market Anderson et al. 2015; Fletcher and Sergeyev, 2002). We thus control for the ethnicity of the women. We account for the three main ethnic groups (Kyrgyz, Uzbek, Russian) and

\footnotetext{
${ }^{9}$ Among women who co-reside with in-laws, 34 percent live with only the mother-in-law, 8 percent with only the father-in-law, and 58 percent with both mother-in-law and father-in-law. Among the few women who co-reside with own parents, 55 percent live with their mother and 45 percent with both parents.
} 
summarize the remaining groups as "other ethnicity", 10 Our second set of variables relates to the residence of the women. This set helps us account for geographic heterogeneity. Economic conditions, and with them labour markets, vary largely within the country. The North is historically more economically developed than the South and urban areas more than rural areas (Fletcher and Sergeyev, 2002, Anderson and Pomfret, 2002). We thus include dummy variables for south Kyrgyzstan as well as urban areas. We also have information on the local availability of child care facilities. As such facilities ease women's integration in the labour market, we control for whether the community in which a woman lives has a kindergarten. Finally, a third set of variables relates to the husband. We control for the husband's educational attainment, because determinants of the husband's income might affect a woman's decision to work. Education of the husband might furthermore capture attitudes on gender roles which are relevant for the woman's labour market participation.

\section{Empirical Strategy and Results}

\section{Discussion of Instrument and Identifying Assumptions}

Earlier studies on the effect of intergenerational co-residence on female labour market outcomes use a variety of instrumental variables to control for the endogeneity of co-residence. Sasaki (2002) uses sibling characteristics (number of siblings and birth order of husband and wife) and housing information (house owned or rented, detached house or apartment, house size) as instruments. Oishi and Oshio (2006) enrich this set of instruments with information on, for example, the husband's age and educational attainment. The instruments in the Maurer-Fazio et al. (2011) study are the percentage of households in the prefecture that have co-resident parents, husband's age, wife's age and provincial dummies. Shen et al. (2016) exploit a tradition about co-residence via sibling structures. They use the number of surviving brothers and sisters of a woman as well as her birth order as instruments for co-residing with

\footnotetext{
10"Other ethnicity" is mainly composed of Dungans, Uigurs, Tajiks and Kazakhs, but contains a number of other small ethnic groups as well.
} 
the woman's parents. This identification strategy is the most similar to ours.

All of the instruments used in the previous literature are relevant and explain the co-residence decision well. However, some of them may not be valid instruments. For example, housing conditions, husband's educational attainment, living in a particular province, and the number of siblings are unlikely to affect female labour supply only through co-residence: housing conditions as well as the number of siblings reflect the wealth of a family, husband's education is a proxy for spousal income, and provincial dummies capture labour market differences across provinces, all of which may influence female labour supply. Thus, we consider it possible that the exclusion restriction is not fulfilled. Sasaki (2002), Oishi and Oshio (2006), Maurer-Fazio et al. (2011) and Shen et al. (2016) do not provide evidence to refute this possibility.

We argue that the instrument that we use in this paper is both relevant and plausibly valid. It is derived from a Central Asian tradition, according to which the youngest son of a family is supposed to stay with his parents and to ensure their well-being (Bauer et al., 1997; Thieme, 2014; Rubinov, 2014). Any woman who is married to a youngest son is thus substantially more likely to co-reside with parentsin-law than a woman who is married to an older sibling. This could already be seen from our descriptive statistics in Table 1; and our first-stage estimation results (see below) provide further support. A dummy variable that indicates whether a woman's husband is the youngest son thus provides a relevant instrument for co-residence.

In all of our estimations, we control for the age of the husband, the number of brothers of the husband, and the age of the oldest living parent of the husband. We refer to these variables as conditioning variables. They are included because they are, by construction, correlated with being the youngest son. Youngest sons are on average younger than older sons; the probability of being the youngest son decreases with the number of brothers; and conditional on son's age, parents of youngest sons tend to be older than parents of older sons. Given these relationships, being married to the youngest son may influence female labour supply through other channels than through co-residence. For example, younger sons who are of the same 
age as older sons tend to have older parents. Older parents, in turn, are likely to require more care, which potentially reduces female labour supply. Controlling for the conditioning variables blocks such channels, which may otherwise violate the exclusion restriction. In contrast to Sasaki (2002), Oishi and Oshio (2006) and Shen et al. (2016), we control for the number of siblings (the number of brothers, to be precise) rather than using it as a separate instrument.

Several threats to the crucial exclusion restriction remain. First, we need to assure that there is no selection on the marriage market in the sense that women with certain characteristics get married to youngest sons. One could think of anticipation effects: women who are willing to care for a parent-in-law and are less prone to participate in the labour force might be more likely to marry a youngest son, as this would result in co-residence with in-laws. Second, we need to rule out that youngest sons have low career ambitions or have a preference for partners with low career ambitions. Youngest sons are likely aware of the responsibility for their parents and could look for a wife willing to share this responsibility with them. Third, we assume that being married to the youngest son has no effect on marital stability. If, for example, the wives of youngest sons are more likely to divorce (possibly due to the responsibility for parents-in-law), they might be more active on the labour market in anticipation of divorce.

In contrast to prior studies with an instrumental variable strategy - which all face these challenges - we explicitly test the plausibility of the exclusion restriction. To address the first two assumptions, we compare pre-marriage characteristics between (a) women married to youngest sons and women married to older sons and (b) men who are the youngest son and men who are an older son. Panel A of Table 2 reports the results for women. We regress a number of pre-marriage characteristics on a dummy variable indicating whether a woman is married to a youngest son, controlling for our conditioning variables. The pre-marriage characteristics are sociodemographic characteristics (age at marriage, ethnicity, number of siblings), proxy variables for labour market affinity (years of education, an indicator for having 
more than 11 years of education, employment status one and two years prior to the marriage) and a proxy for the prevalence of traditional values (evolution of the marriage decision). With regard to the latter point, we distinguish between love marriage, arranged marriage, and bride capture with the latter two representing traditional values (Nedoluzhko and Agadjanian, 2015, Becker et al., 2017), which have potential implications for labour market outcomes of females.

\section{[INSERT TABle 2 about here]}

We estimate a logit model if the pre-marriage characteristic is binary and an OLS model if it is continuous. Column (1) presents the coefficient for being married to the youngest son, column (2) the standard error and column (3) the t-statistic/zstatistic. As can be seen from the last column, we do not find differences at the 5 percent significance level. Panel B of Table 2 compares pre-marriage characteristics for youngest sons and older sons, and we find no differences in these characteristics. We conclude that couples involving a youngest son do not seem to self-select in terms of labour market characteristics at the time of marriage.11

Last, we want to rule out any effect of being married to a youngest son on marriage stability. More precisely, we would like to find out whether divorced women are significantly more likely to have been married to youngest sons compared with older sons ${ }^{12}$ We cannot test this assumption with our sample because all women in the sample are married. We instead use information on all brothers of the husband, including information of the husband himself, and all brothers of the women in our sample. ${ }^{13}$ Their marital status and their birth order are known. We compare the likelihood of being divorced between male siblings who are the youngest son and those who are not the youngest son. We estimate a logit model for the probability of divorce. Divorce is estimated as a function of the son's birth order and the conditioning variables. Based on a sample of 5,679 male siblings, the marginal effect of

\footnotetext{
${ }^{11}$ In addition we use a non-parametric matching method in order to test for differences in pre-marriage characteristics. We also do not find significant differences (see Table A.3 in the Appendix).

${ }^{12}$ Divorce is rare but exists in Kyrgyzstan. The divorce rate, according to the $2011 \mathrm{LIK}$, is $4 \%$.

${ }^{13}$ The list of siblings of all wives and husbands was compiled during the supplementary data collection in 2014 , with the aim to identify the youngest son in every family.
} 
being the youngest son is -0.002 ; the corresponding z-statistic is -0.75 . We conclude that couples involving a youngest son do not differ with respect to marriage stability from other couples ${ }^{14}$

\section{Estimation Results}

We estimate the effect of co-residence with parents or in-laws on labour market outcomes of women using a two-stage least squares estimation. ${ }^{15}$ For the effect on labour force participation, the estimation equations for the two stages are:

$$
\begin{aligned}
\text { Co-residence }_{i} & =\alpha_{1}+\alpha_{2} \text { Youngest Son }_{i}+\alpha_{3} X_{i}+\epsilon_{i} \\
\text { LFP }_{i} & =\beta_{1}+\beta_{2} \text { Co-residence }_{i}+\beta_{3} X_{i}+v_{i}
\end{aligned}
$$

where $i$ indexes individual women. Co-residence ${ }_{i}$ is a dummy variable that captures whether a woman lives with at least one parent or parent-in-law in the same

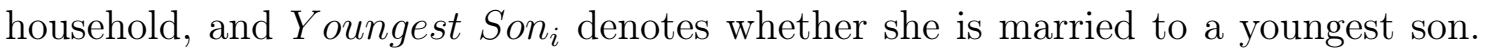
$L F P_{i}$ is her labour force participation. $X_{i}$ is a vector of control variables, including the characteristics of the woman (age, educational attainment, ethnicity), the residence (community is located in south Kyrgyzstan, community is urban, availability of kindergarten) and the husband (educational attainment). We also control for the conditioning variables, i.e. the age, the number of brothers, and the age of the oldest living parent of the husband.

Unlike related papers (Sasaki, 2002, Oishi and Oshio, 2006; Maurer-Fazio et al., 2011, Shen et al., 2016), we do not control for the number of children in the household because this variable turns out to be a bad control in our context. The number of children is determined by being married to the youngest son. To illustrate this, we regress the number of children up to age five on being married to the youngest son, controlling for the conditioning variables. We restrict this exercise to the number of

\footnotetext{
${ }^{14}$ As before, we additionally use a non-parametric matching method to test for differences in marriage stability between youngest and non-youngest sons. In accordance with our parametric result, we do not find a significant difference.

${ }^{15}$ Note that - as in every IV estimation - the treatment effect has a local interpretation, i.e. it is the effect for women who live with the parent generation only because they are married to a youngest son.
} 
children up to age five because these children are not yet in school and are most likely to affect female labour supply. There is a positive and significant relationship between the number of children and being married to the youngest son (Table A.4 in the Appendix). We subsequently estimate the effect of co-residence on the number of children, instrumenting co-residence with being married to the youngest son. We find that, ceteris paribus, co-residing couples have 0.5 more children in the household (Table A.5 in the Appendix). Since we are interested in establishing causality between co-residence and female labour supply, controlling for the number of children would be inappropriate.

In the first stage of the estimation (equation (1)), the endogenous variable (coresidence) is treated as a linear function of the instrument (being married to the youngest son) and the remaining control variables $\left(X_{i}\right)$. In the second stage (equation (2)), we estimate a linear probability model and replace co-residence with the predicted values from the first stage $\left(\right.$ Co-residence $\left._{i}\right) . \beta_{2}$ is the unbiased effect of co-residence on female labour force participation. The main two-stage estimation results are in Panel B of Table 3; the main OLS results are in Panel A. Full estimation results are reported in Tables A.6, A.7, and A.8 in the Appendix.

\section{[INSERT TABLE 3 ABOUT HeRE]}

The estimation equations for the effect of co-residence on hours of work are:

$$
\begin{aligned}
\text { Co-residence }_{i} & =\alpha_{1}+\alpha_{2} \text { Youngest Son }_{i}+\alpha_{3} X_{i}+\epsilon_{i} \\
W^{*}{ }_{i} & =\gamma_{1}+\gamma_{2} \text { Co-residence }_{i}+\gamma_{3} X_{i}+\mu_{i}
\end{aligned}
$$

where $W H^{*}{ }_{i}$ is the linear index determining working hours $W H_{i}\left(W H_{i}=0\right.$ if $W H^{*}{ }_{i} \leq 0, W H_{i}=W H^{*}{ }_{i}$ if $\left.W H^{*}{ }_{i}>0\right)$. All other variables are defined as above. The first stage is identical to equation (1). We slightly adapt our approach for the second stage and employ an IV Tobit model to account for the censored nature of the dependent variable. The main IV Tobit estimation results are presented in Panel B of Table 4. The main Tobit results are shown in Panel A. Full estimation results 
are reported in Tables A.9 and A.10 in the Appendix.

\section{[INSERT TABle 4 ABOUt HeRE]}

The first stage results show that being married to the youngest son has a positive and highly significant effect on intergenerational co-residence. Women who married a youngest son are 21 percentage points more likely to co-reside compared with women who married an older son (Table 3 or 4 , column (5)). We test for strength of the instrument and report the relevant F-statistics in Tables 3 and 4 . The F-statistic is $>40$ in all specifications and hence sufficiently large to rule out weak instrument problems (Staiger and Stock, 1997).

Instrumenting co-residence with being married to the youngest son in all specifications yields a negative effect which is larger in magnitude than in the corresponding OLS regression. When we compare the OLS and IV regressions with a Hausman test, we cannot reject the consistency of OLS; both OLS and IV models produce consistent parameter estimates. In column (1) of Table 3, we estimate a significant effect of -20 percentage points on female labour force participation (-17 percentage points in the OLS). Including the control variables in columns (2)-(5) reduces the effect to between -8 to -10 percentage points ( -2 to -6 percentage points in the OLS) and makes it insignificant. A similar picture emerges when we analyze the effect of co-residence on working hours (Table 4). In column (1), co-residence significantly reduces the number of women's working hours by 20 hours (14 hours in the Tobit) per week. Adding control variables reduces the effect to between -12 and -15 hours (-1 to -4 hours in the Tobit) per week (columns (2)-(5)) and this effect is again insignificant. ${ }^{16}$ The effect sizes - though insignificant - are not negligible.

We observe that, once we control for the conditioning variables in column (2) in Tables 3 and 4 , the estimated effects do not change much with the inclusion of the additional control variables in columns (3)-(5). The key variable is the age of the husband, which proxies the age of the woman. Younger women are more likely to

\footnotetext{
${ }^{16}$ We also ran an IV estimation for the impact of co-residence on the number of working hours of only those women with positive working hours. The results are again negative but statistically insignificant.
} 
co-reside (Table A.7), are less likely to participate in the labour force (Tables A.6 and A.8), and work fewer hours (Tables A.9 and A.10). Controlling for the age of the woman, either explicitly in columns (3)-(5) or implicitly in column (2), therefore reduces the stark difference in labour force participation and working hours between co-residing and non-co-residing women.

We tested for heterogeneity in the effect of intergenerational co-residence on female labour supply among different groups but never obtained significant results. Although labour markets differ substantially between urban and rural areas in Kyrgyzstan, co-residence significantly influences female labour supply neither in urban areas nor in rural areas. Furthermore, living with the parent generation has no significant influence on the labour supply of women with low education, women with medium education and women with high education and also women in the age ranges 20-29, 30-39, and 40-50. Intergenerational co-residence merely seems to not matter for women's labour market decisions.

\section{Comparison of Estimated Effects with Other Countries}

Previous empirical studies on the labour market effects of intergenerational coresidence invariably find a positive impact. These studies use data from the US (Kolodinsky and Shirey, 2000), Japan (Sasaki, 2002, Oishi and Oshio, 2006), and China (Maurer-Fazio et al., 2011; Shen et al., 2016). Among these countries, patrilocality is common in China (Ebenstein, 2014) and, to a lesser extent, in Japan (Takagi et al., 2007). Yet, the studies on China do not capture the full extent of patrilocality. Maurer-Fazio et al. (2011) focus on urban China, where patrilocality is much less practised than in rural China ${ }^{17}$, and Shen et al. $(2016)$ fully exclude patrilocality by restricting their analysis to women's co-residence with own parents.

Interestingly, the magnitude of the estimated impacts is smaller in settings with

\footnotetext{
${ }^{17}$ The Global Data Lab database (Institute for Management Research, Radboud University, 2017) reports a patrilocality index of 0.81 for urban China and of 2.55 for rural China. The patrilocality index is the log of the percentage of patrilocal residence divided by the percentage of matrilocal residence. This means the larger the value the more patrilocal is the setting. For comparison, Kyrgyzstan has a mean patrilocality index of 2.31 at the national level in the period 2000-2016.
} 
a higher prevalence of patrilocality. Living with parents or in-laws increases the probability of female labour force participation by 56 percentage points in the US (Kolodinsky and Shirey, 2000), by 28 percentage points in China when analysis is limited to co-residence with own parents (Shen et al., 2016), by 19-24 percentage points in Japan (Oishi and Oshio, 2006), and by 7 percentage points in urban China (Maurer-Fazio et al., 2011). We compare our estimated effects for Kyrgyzstan to these numbers. Taking the full model (column (5) of Table 3) as a reference point, we can reject that our OLS estimate is larger or equal to the smallest effect that had previously been estimated (0.07 in Maurer-Fazio et al. (2011)). For the IV estimate, which has a much larger variance, we can still reject that it is larger or equal to the second smallest effect (0.19 in Oishi and Oshio (2004)). Our estimates hence appear to be less positive than what most previous findings suggest. Since Kyrgyzstan has the highest prevalence of patrilocality among these samples, this finding fits well into the pattern.

\section{Channels}

We find that co-residence with parents or in-laws does not significantly affect female labour supply in Kyrgyzstan. In the following, we examine all four channels mentioned in Section 1, through which co-residence may influence the labour market outcomes of women. For two channels, we can conduct a causal analysis; for the other two channels, we can only provide descriptive evidence.18

First, we exploit information on the time use of the women in our estimation sample. We run an instrumental variable estimation in which hours spent on elder care, housekeeping, and child care are outcome variables. We expect that co-residence leads to more time spent on elder care and housekeeping Grogan, 2013, Ebenstein, 2014) and less time spent on child care. Grandparents - and especially grandmothers - are known to be heavily involved in child care in Kyrgyzstan (Kuehnast, 2004). Among all women in our sample, 10 percent spend time on elder care (if any, 1.2

\footnotetext{
${ }^{18}$ Descriptive statistics of the channel variables can be found in Table A.11 in the Appendix.
} 
hours per day on average), 96 percent spend time on housekeeping (if any, 5.6 hours per day on average), and 64 percent spend time on child care (if any, 2.8 hours per day on average).

\section{[INSERT TABle 5 about here]}

Table 5 reports the results. Co-residence with parents or in-laws leads to one more hour spent per day on elder care, on average (IV estimate in column (1)). This finding fits well into the previous literature on patrilocal societies. This literature argues that sons are much more valued by parents than daughters because parents of sons enjoy elder care within the house provided by the daughter-in-law whereas parents of daughters have no caretakers (Ebenstein, 2014). This differential valuation leads to the fact that women in patrilocal societies tend to have fewer children if the first born was a male (Grogan, 2013). Ebenstein (2014) argues that parents are even willing to abort daughters because daughters will not be able to provide elder care.

In contrast, co-residence does not significantly influence the time spent by women on housekeeping or child care (columns (2) and (3)). The point estimates for child care are positive for both OLS and IV estimation. They indicate that co-residing women spend slightly more time on child care than other women, which is plausible since co-residing women have more small children. However, these estimates are not statistically significant and should not be given much weight. For housekeeping, the point estimates are positive and significant in the OLS estimation but negative and insignificant (with large standard errors) in the IV estimation, which makes it hard to detect a tendency. In any case, we cannot confirm substantial parental assistance related to child care or housekeeping in Kyrgyzstan, in contrast to what was suggested by the previous literature for the US, Japan and China.

Second, we exploit variation in income provided to the household by the parent generation and in gender attitudes of parents and in-laws. Because we rely on information provided by the parents or in-laws themselves, we here need to restrict our 
sample to those households where women are co-resident. Instead of a causal analysis, we therefore investigate whether parents' or in-laws' income and gender attitudes are related with female labour force participation and the number of working hours. We control for the same variables as above, except for the conditioning variables ${ }^{19}$ This exercise serves as a plausibility check for the income and gender attitudes channels mentioned in Section 1, the results have no causal interpretation. Estimation results are found in Table 6 (OLS for labour force participation and Tobit for working hours).

\section{[INSERT TABLE 6 ABOUt HeRE]}

In terms of labour income, we restrict attention to income from dependent employment, because we are interested in the pure income effect and want to rule out effects on female labour supply from family-owned businesses that may provide employment to women. Among all intergenerational households, 86 (17\%) benefit from labour income of the parents or in-laws; and 301 (63\%) from pension income. In households with labour income, the average earned per month is 7,990 Som (approx. 173 US\$). In households with pension income, the average monthly pension is 4,450 Som (approx. 96 US\$). As expected, we observe a negative correlation between parents' or in-laws' income and the labour supply of the co-residing women (columns (1) and (3)). However, the estimates are not statistically significant.

We measure the gender attitudes of parents or in-laws in terms of their expressed attitudes towards the role of females in society. LIK respondents reported their level of agreement on a four-point Likert scale ranging from Strongly disagree (1) to Strongly agree (4) on seven statements. A list of these statements can be found in Table A.12 in the Appendix. We conduct a factor analysis to extract one single latent factor from the seven statements. To facilitate interpretation, we use a standardized index ranging from lower traditional attitudes (lower index values) to stronger traditional attitudes (higher index values). Our estimation results suggest

\footnotetext{
${ }^{19}$ The conditioning variables are neglected because we restrict the analysis to only co-residing households and do not use information on being married to the youngest son.
} 
that the gender attitudes of parents or in-laws are unrelated to female labour force participation and working hours (columns (3) and (6)).

\section{Conclusion}

We investigate the role of co-residence with the parent generation for labour market outcomes of married women in Kyrgyzstan, a patrilocal society in Central Asia. We find that co-residence has no significant effect on labour force participation and the number of working hours of females. Point estimates in both OLS and IV estimation are always negative and we can reject the null hypothesis that these estimates are equal or larger than most of the positive estimates of prior studies. These prior studies are from contexts where patrilocal residence rules are of relatively little importance, suggesting that the impact of intergenerational co-residence on female labour may depend on the extent of patrilocality within a society. Due to the expectations on married women, living with the parent generation is less conducive to female activity on the labor market in patrilocal societies.

To substantiate our results, we investigate the channels through which living with the parent generation affects the labour market activity of females in Kyrgyzstan. Importantly, women who co-reside do not differ significantly from women who do not co-reside in terms of time spent on housekeeping and child care. This fact makes our setting different from the prior evidence, as parents and in-laws in China, Japan and the US are assumed to provide substantial assistance with housekeeping and child care. In Kyrgyzstan, we do not find evidence for such parental assistance. At the same time, co-residing women spend significantly more time on elder care than women who do not co-reside in Kyrgyzstan. It appears that, in our patrilocal context, intergenerational co-residence is a living arrangement which does not relieve women from time-consuming tasks within the household and does not facilitate female labor supply. 


\section{References}

Akiner, S. (1997). Between tradition and modernity - the dilemma facing contemporary Central Asian women. In M. Buckley (ed.), Post - Soviet Women: From the Baltic to Central Asia, Cambridge: Cambridge University Press, pp. 261-304.

Anderson, K., Esenaliev, D. and Lawler, E. (2015). Gender Earnings Inequality After the 2010 Revolution: Evidence from the Life in Kyrgyzstan Surveys, 2010-2013. Tech. rep., Unpublished manuscript.

Anderson, K. H. and Pomfret, R. (2002). Relative living standards in new market economies: Evidence from Central Asian household surveys. Journal of Comparative Economics, 30 (4), 683-708.

BAKer, M. J. and JACOBSEn, J. P. (2007). A human capital-based theory of postmarital residence rules. Journal of Law, Economics, and Organization, 23 (1), 208-241.

Bauer, A., Green, D. and Kuehnast, K. (1997). Women and gender relations: the Kyrgyz Republic in transition. Asian Development Bank.

Becker, C. M., Mirkasimov, B. and Steiner, S. (2017). Forced marriage and birth outcomes. Demography, DOI: 10.1007/s13524-017-0591-1.

Brück, T., Esenaliev, D., Kroeger, A., Kudebayeva, A., Mirkasimov, B. and Steiner, S. (2014). Household survey data for research on well-being and behavior in Central Asia. Journal of Comparative Economics, 42 (3), 819 - 835.

Chu, C. C., Kim, S. and Tsay, W.-J. (2014). Coresidence with husband's parents, labor supply, and duration to first birth. Demography, 51 (1), 185-204.

Compton, J. (2015). Family proximity and the labor force status of women in Canada. Review of Economics of the Household, 13 (2), 323-358.

- and Pollak, R. A. (2014). Family proximity, childcare, and womens labor force attachment. Journal of Urban Economics, 79, 72-90.

Ebenstein, A. (2014). Patrilocality and Missing Women. Tech. rep., Unpublished manuscript.

EtTneR, S. L. (1996). The opportunity costs of elder care. Journal of Human Resources, 31 (1), 189-205.

Fletcher, J. F. and Sergeyev, B. (2002). Islam and intolerance in central asia: The case of Kyrgyzstan. Europe-Asia Studies, 54 (2), 251-275.

García-Morán, E. and KueHn, Z. (2017). With strings attached: grandparentprovided child care and female labor market outcomes. Review of Economic Dynamics, 23, 80-98.

Giddings, L., Meurs, M. and Temesgen, T. (2007). Changing preschool enrolments in post-socialist Central Asia: Causes and implications. Comparative Economic Studies, 49 (1), 81-100.

Giovarelli, R., Aidarbekova, C., Duncan, J., Rasmussen, K. and TaByshalieva, A. (2001). Women's rights to land in the Kyrgyz Republic. Http://landwise.resourceequity.org/records/2426 (accessed on April 21, 2017). 
Grogan, L. (2013). Household formation rules, fertility and female labour supply: Evidence from post-communist countries. Journal of Comparative Economics, 41 (4), 1167-1183.

Ibraeva, G., Moldosheva, A. and Niyazova, A. (2011). Gender Equality and Development: Kyrgyz Country Case Study. Background paper for World Development Report 2012. Tech. rep., Washington, DC: World Bank.

Institute For Management Research, RAdboud University (2017). Global data lab. Https://globaldatalab.org/ (accessed on May 30, 2017).

Kolodinsky, J. and Shirey, L. (2000). The impact of living with an elder parent on adult daughter's labor supply and hours of work. Journal of Family and Economic Issues, 21 (2), 149-175.

Kuehnast, K. (2004). Kyrgyz. In C. Ember and M. Ember (eds.), Encyclopedia of Sex and Gender. Men and Women in the World's Cultures, Kluwer Academic, pp. 592-599.

Lilly, M. B., Laporte, A. and Coyte, P. C. (2007). Labor market work and home care's unpaid caregivers: A systematic review of labor force participation rates, predictors of labor market withdrawal, and hours of work. Milbank Quarterly, 85 (4), 641-690.

MA, S. and Wen, F. (2016). Who coresides with parents? An analysis based on sibling comparative advantage. Demography, 53 (3), 623-647.

Maurer-Fazio, M., Connelly, R., Chen, L. and Tang, L. (2011). Childcare, eldercare, and labor force participation of married women in urban China, 19822000. Journal of Human Resources, 46 (2), 261-294.

MinceR, J. (1958). Investment in human capital and personal income distribution. Journal of Political Economy, 66 (4), 281-302.

Ministry of Labour And Social Development (2017). Sotsialnye utschreschdeniya. Http://www.mlsp.gov.kg/?q=ru/sotsuchrejdeniya (accessed April 3, 2017).

Murdock, G. P. (1967). Ethnographic Atlas. Pittsburgh: University of Pittsburgh Press.

Nedoluzhko, L. and Agadjanian, V. (2015). Between tradition and modernity: Marriage dynamics in kyrgyzstan. Demography, 52 (3), 861-882.

Oishi, A. S. and Oshio, T. (2006). Coresidence with parents and a wife's decision to work in Japan. The Japanese Journal of Social Security Policy, 5 (1), 35-48.

PACI, P. et al. (2002). Gender in transition. World Bank Washington, DC.

Posadas, J. and VidAl-Fernández, M. (2013). Grandparents' childcare and female labor force participation. IZA Journal of Labor Policy, 2 (1), 1-20.

Rubinov, I. (2014). Migrant assemblages: Building postsocialist households with Kyrgyz remittances. Anthropological Quarterly, 87 (1), 183-215.

SASAKI, M. (2002). The causal effect of family structure on labor force participation among Japanese married women. Journal of Human Resources, 37 (2), 429-440. 
Schwegler-Rohmeis, W., Mummert, A. and Jarck, K. (2013). Labour Market and Employment Policy in the Kyrgyz Republic. Tech. rep., Bishkek: GIZ.

Shen, K., YAn, P. and ZENG, Y. (2016). Coresidence with elderly parents and female labor supply in China. Demographic Research, 35 (23), 645-670.

Staiger, D. and Stock, J. H. (1997). Instrumental variables regression with weak instruments. Econometrica, 65 (3), 557-586.

Takagi, E., Silverstein, M. and Crimmins, E. (2007). Intergenerational coresidence of older adults in japan: Conditions for cultural plasticity. The Journals of Gerontology Series B: Psychological Sciences and Social Sciences, 62 (5), S330S339.

Thieme, S. (2014). Coming home? Patterns and characteristics of return migration in Kyrgyzstan. International Migration, 52 (5), 127-143.

UNICEF (2017). Transmonee database. Http://www.transmonee.org (accessed on April 3, 2017). 


\section{Tables and Figures}

Figure 1: Co-Residence and Female Labour Force Participation Across Countries

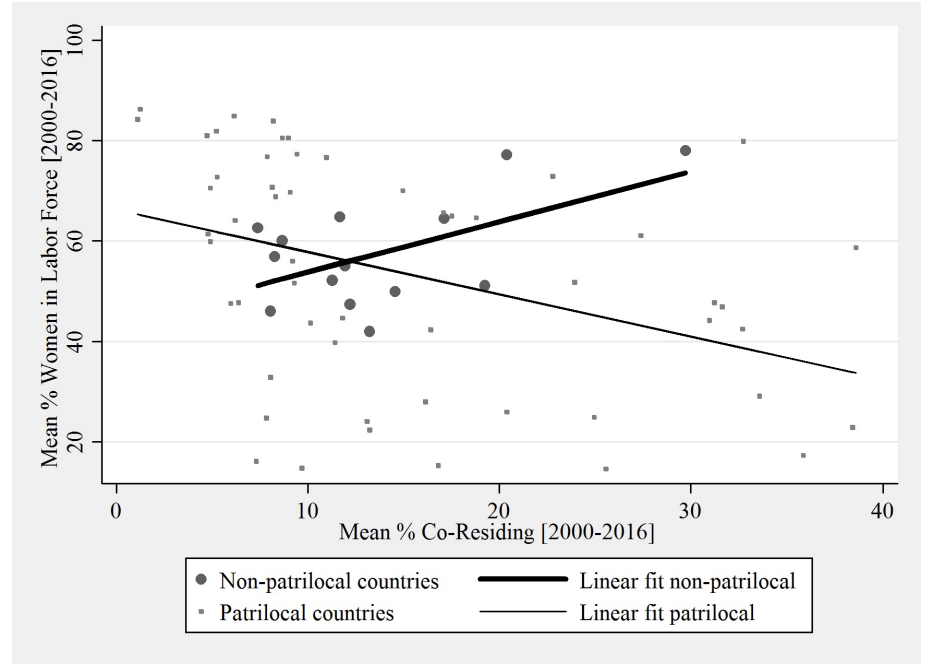

Source: Data from Global Data Lab (co-residence) and World Development Indicators (female labour force participation). The Global Data Lab provides data on 104 countries, out of which 102 have co-residence measures between 1990 and 2016. For 101 countries, we can match female labour force participation. Our analysis focuses on 68 countries with a population greater than 5 million. Results hold when including smaller countries.

Note: Patrilocal countries are those in which more couples live with the husband's than the wife's parents; non-patrilocal countries are all others. The slope of the estimated lines is $1.01(\mathrm{~N}=14, \mathrm{p}$-value $=0.036)$ for non-patrilocal countries and $-0.84(\mathrm{~N}=54$, p-value $=0.004)$ for patrilocal countries. 
Figure 2: Labour Force Participation in Kyrgyzstan, 1990-2016

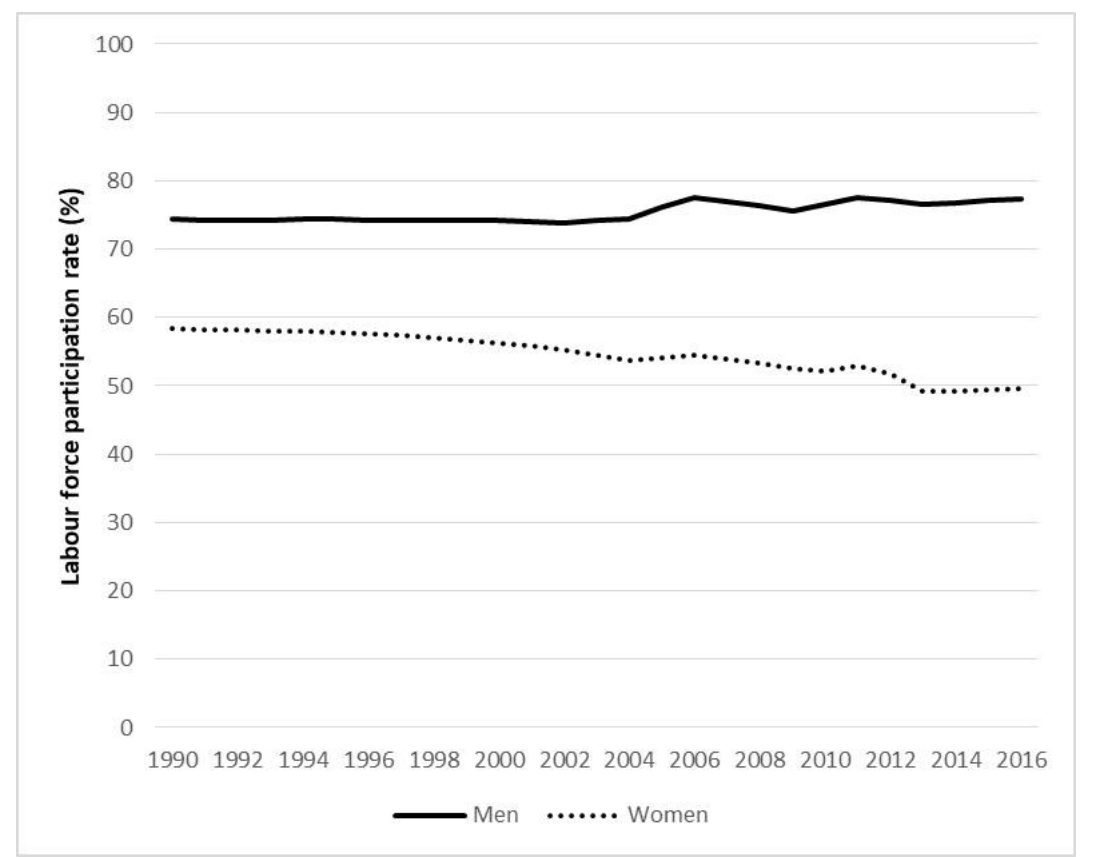

Source: World Development Indicators, World Bank 
Table 1: Co-Residence, Female Labour Supply, and Married to Youngest Son

\begin{tabular}{|c|c|c|c|}
\hline & \multirow{3}{*}{$\begin{array}{c}(1) \\
\text { All }(n=1,048)\end{array}$} & $(2)$ & (3) \\
\hline & & \multicolumn{2}{|c|}{ Co-residence } \\
\hline & & Yes $(n=501)$ & No $(n=547)$ \\
\hline \multirow[t]{2}{*}{ Labour force participation (share) } & 0.48 & 0.39 & 0.56 \\
\hline & $(0.50)$ & $(0.49)$ & $(0.50)$ \\
\hline \multirow[t]{2}{*}{ Working hours (mean $)^{a}$} & 35.97 & 35.32 & 36.38 \\
\hline & $(14.30)$ & $(14.42)$ & $(14.24)$ \\
\hline \multirow[t]{2}{*}{ Married to youngest son (share) } & 0.35 & 0.50 & 0.21 \\
\hline & $(0.48)$ & $(0.50)$ & $(0.41)$ \\
\hline
\end{tabular}

Source: Life in Kyrgyzstan (LIK) Survey, wave 2011, own calculations. Notes: Standard deviation in parentheses.

${ }^{a}$ Working hours are calculated based on the sample of employed women. 
Table 2: Differences in Pre-Marriage Characteristics

\begin{tabular}{|c|c|c|c|}
\hline & $\begin{array}{c}\text { (1) } \\
\text { Coefficient/Marginal Effect }\end{array}$ & $\begin{array}{l}(2) \\
\text { S.E. }\end{array}$ & $\begin{array}{c}(3) \\
\text { Z-Stat/T-Stat }\end{array}$ \\
\hline \multicolumn{4}{|l|}{ A. Wife } \\
\hline Age at marriage $^{c}$ & 0.47 & 0.24 & 1.93 \\
\hline Kyrgyz & -0.01 & 0.04 & -0.14 \\
\hline Uzbek & -0.03 & 0.03 & -1.01 \\
\hline Russian & 0.02 & 0.01 & 1.36 \\
\hline Other ethnicity & -0.01 & 0.02 & -0.52 \\
\hline Total number of siblings ${ }^{c}$ & -0.07 & 0.16 & -0.47 \\
\hline Years of education $^{c}$ & 0.24 & 0.18 & 1.33 \\
\hline More than 11 years of education & 0.05 & 0.04 & 1.28 \\
\hline Worked $\mathrm{t}-1$ if $\mathrm{t}=$ year of marriage & 0.01 & 0.04 & 0.34 \\
\hline Worked $\mathrm{t}-2$ if $\mathrm{t}=$ year of marriage & 0.02 & 0.03 & 0.61 \\
\hline Love marriage & 0.03 & 0.04 & 0.92 \\
\hline Arranged marriage & -0.02 & 0.03 & -0.44 \\
\hline Bride capture & -0.02 & 0.02 & -0.78 \\
\hline \multicolumn{4}{|l|}{ B. Husband } \\
\hline Age at marriage $^{c}$ & 0.52 & 0.31 & 1.69 \\
\hline Kyrgyz & -0.01 & 0.04 & -0.32 \\
\hline Uzbek & -0.04 & 0.03 & -1.28 \\
\hline Russian & 0.02 & 0.01 & 1.31 \\
\hline Other ethnicity & 0.002 & 0.02 & 0.13 . \\
\hline Total number of siblings ${ }^{c}$ & 0.07 & 0.11 & 0.60 \\
\hline Years of education $^{c}$ & -0.03 & 0.18 & -0.18 \\
\hline More than 11 years of education & -0.002 & 0.04 & -0.07 \\
\hline Worked $\mathrm{t}-1$ if $\mathrm{t}=$ year of marriage & 0.04 & 0.04 & 0.93 \\
\hline Worked $\mathrm{t}-2$ if $\mathrm{t}=$ year of marriage & 0.01 & 0.04 & 0.33 \\
\hline
\end{tabular}

Source: Life in Kyrgyzstan (LIK) Survey, wave 2011, own calculations.

Notes: ${ }^{c}$ denotes continuous variable.

Panel A shows the effect of being married to the youngest son of a family on pre-marriage characteristics of the wife. Panel B shows the effect of being a youngest son of a family on pre-marriage characteristics of the husband. Results are based on Logit estimations for binary outcome variables and ordinary least-squares (OLS) estimations for continuous outcomes. Column (1) reports the Logit marginal effect or OLS coefficient of the variable youngest son, while further controlling for number of brothers of the husband, age of the husband and age of the oldest living parent of the husband. Column (2) reports the corresponding standard errors, column (3) the values of z-statistic (for Logit estimations) or t-statistic (for OLS estimations). Critical values of t-distribution: $t_{\infty, 0.95}=1.645, t_{\infty, 0.975}=1.96, t_{\infty, 0.995}=2.576$. 
Table 3: Estimation Results: Labour Force Participation

(1) (2) (3)

(2) (3)

A. OLS Estimation Results

(Co-residence exogenous)

Co-residence

$-.168^{* * *}$

$(0.03)$

$-.057$

$(0.036)$

$-.023$

$(0.037)$

$-.049$

$(0.037)$

$-.050$

B. Two-stage Least-Squares Estimation Results (Co-residence endogenous)

First Stage

Youngest son

F-statistic

$\begin{array}{ccccc}0.316^{* * *} & 0.204^{* * *} & 0.21^{* * *} & 0.216^{* * *} & 0.214^{* * *} \\ (0.031) & (0.032) & (0.031) & (0.03) & (0.03) \\ 104.104 & 41.637 & 46.865 & 51.254 & 50.192\end{array}$

Second Stage

Co-residence

Observations

$-.196$

$(0.101)$

$-.084$

$(0.185)$

$-.106$

$-.097$

$(0.169)$

$-.102$

1,048

1,048

1,048

1,048

(0.171)

Conditioning Variables

Wife Characteristics

Residence Characteristics

Husband Characteristics

Source: Life in Kyrgyzstan (LIK) Survey, wave 2011, own calculations.

Notes: Standard errors in parentheses. ${ }^{*} p<0.1,{ }^{* *} p<0.05,{ }^{* * *} p<0.01$.

Conditioning variables: age of the husband, number of brothers of the husband, age of the oldest living parent of the husband.

Wife characteristics: age, educational attainment, ethnicity.

Residence characteristics: community is located in south Kyrgyzstan, community is urban, availability of kindergarten.

Husband characteristic: educational attainment. 
Table 4: Estimation Results: Working Hours

\section{(1)}

A. Tobit Estimation Results

(Co-residence exogenous)
Co-residence

B. IV Tobit Estimation Results

(Co-residence endogenous)

\section{First Stage ${ }^{a}$}

Youngest son

F-statistic
$-14.241^{* * *}$

(2.672)
(2)

Second Stage

Co-residence

Observations

Conditioning Variables

Wife Characteristics

Residence Characteristics

Husband Characteristics

Source: Life in Kyrgyzstan (LIK) Survey, wave 2011, own calculations.

Notes: Standard errors in parentheses. ${ }^{*} p<0.1,{ }^{* *} p<0.05,{ }^{* * *} p<0.01$.

Conditioning variables: age of the husband, number of brothers of the husband, age of the oldest living parent of the husband.

Wife characteristics: age, educational attainment, ethnicity.

Residence characteristics: community is located in south Kyrgyzstan, community is urban, availability of kindergarten.

Husband characteristic: educational attainment.

$a$ The first stage is identical to the first stage in Table 3 
Table 5: Channel Analysis I: Time Use Woman

\begin{tabular}{|c|c|c|c|}
\hline & $\begin{array}{c}\text { Elder Care } \\
\text { (in hours) } \\
(1)\end{array}$ & $\begin{array}{c}\text { Housekeeping } \\
\text { (in hours) } \\
(2)\end{array}$ & $\begin{array}{c}\text { Child Care } \\
\text { (in hours) } \\
(3)\end{array}$ \\
\hline \multicolumn{4}{|c|}{$\begin{array}{l}\text { A. OLS Estimation Results } \\
\text { (Co-residence exogenous) }\end{array}$} \\
\hline Co-residence & $\begin{array}{c}0.191 * * * \\
(0.036)\end{array}$ & $\begin{array}{c}0.410^{* *} \\
(0.204)\end{array}$ & $\begin{array}{c}0.105 \\
(0.145)\end{array}$ \\
\hline \multicolumn{4}{|c|}{$\begin{array}{l}\text { B. Two-stage Least-Squares Estimation Results } \\
\text { (Co-residence endogenous) }\end{array}$} \\
\hline $\begin{array}{l}\text { Second Stage } \\
\text { Co-residence }\end{array}$ & $\begin{array}{c}0.959 * * * \\
(0.339)\end{array}$ & $\begin{array}{l}-1.449 \\
(1.906)\end{array}$ & $\begin{array}{l}1.114 \\
(0.681)\end{array}$ \\
\hline Observations & 1,048 & 1,048 & 1,048 \\
\hline Conditioning Variables & $\checkmark$ & $\checkmark$ & $\checkmark$ \\
\hline Wife Characteristics & $\checkmark$ & $\checkmark$ & $\checkmark$ \\
\hline Residence Characteristics & $\checkmark$ & $\checkmark$ & $\checkmark$ \\
\hline Husband Characteristics & $\checkmark$ & $\checkmark$ & $\checkmark$ \\
\hline
\end{tabular}

Source: Life in Kyrgyzstan (LIK) Survey, wave 2011, own calculations.

Notes: Standard errors in parentheses. ${ }^{*} p<0.1,{ }^{* *} p<0.05,{ }^{* * *} p<0.01$.

(1) Elder Care (in hours per day): Total time of woman spent for elder care.

(2) Housekeeping (in hours per day): Total time of woman spent for housekeeping (e.g. cooking, washing, laundry, cleaning, shopping, repairs, other household tasks).

(3) Child Care (in hours per day): Total time of woman spent for child care. 
Table 6: Channel Analysis II: Parents' Financial Contributions and Gender Preferences

\begin{tabular}{|c|c|c|c|c|}
\hline & \multicolumn{2}{|c|}{ Labour Force Participation } & \multicolumn{2}{|c|}{ Working Hours } \\
\hline & (1) & $(2)$ & $(3)$ & (4) \\
\hline $\begin{array}{l}\text { Financial contribution to the Household } \\
\text { Income parents (in } 1000 \text { Som) }\end{array}$ & $\begin{array}{l}-0.005 \\
(0.004)\end{array}$ & & $\begin{array}{l}-0.508 \\
(0.536)\end{array}$ & \\
\hline $\begin{array}{l}\text { Preferences of Parents } \\
\text { Gender attitudes (std.) }\end{array}$ & & $\begin{array}{c}0.003 \\
(0.022)\end{array}$ & & $\begin{array}{c}1.095 \\
(2.184)\end{array}$ \\
\hline Observations & 501 & 490 & 501 & 490 \\
\hline Wife Characteristics & $\checkmark$ & $\checkmark$ & $\checkmark$ & $\checkmark$ \\
\hline Residence Characteristics & $\checkmark$ & $\checkmark$ & $\checkmark$ & $\checkmark$ \\
\hline Husband Characteristics & $\checkmark$ & $\checkmark$ & $\checkmark$ & $\checkmark$ \\
\hline
\end{tabular}

Source: Life in Kyrgyzstan (LIK) Survey, wave 2011, own calculations.

Notes: Standard errors in parentheses. ${ }^{*} p<0.1,{ }^{* *} p<0.05,{ }^{* * *} p<0.01$.

The analysis is restricted to only co-residing women.

(1) Income parents (in 1000 Som): Includes income of all co-residing parents earned as employees and pension contributions.

(2) Gender Attitudes (std.): Average gender attitudes of co-residing parents in the household. We define preferences as the parents' attitude towards the role of females in society. Gender attitudes are measured using seven self-reported items. Item responses are reported on a four-point Likert scale ranging from Strongly disagree (1) to Strongly agree (4). We identify two liberal and five traditional items. We then use all items to conduct a factor analysis and to extract one single latent factor. To facilitate the interpretation, we use a standardized index ranging from lower traditional attitudes (lower index values) to stronger traditional attitudes (higher values). 


\section{A Supplementary Tables and Figures}

Table A.1: List of Countries Used for Cross-Country Analysis

\begin{tabular}{|c|c|c|c|}
\hline$(1)$ & $(2)$ & $(3)$ & $(4)$ \\
\hline ISO Code & Country & $\begin{array}{c}\text { \% Couples Living Wife's Parents } \\
\text { mean }\end{array}$ & $\begin{array}{l}\text { \% Couples Living Husband's Parents } \\
\text { mean }\end{array}$ \\
\hline KHM & Cambodia & 15.05 & 5.36 \\
\hline CUB & Cuba & 8.22 & 5.02 \\
\hline $\mathrm{COL}$ & Colombia & 7.08 & 4.87 \\
\hline CHL & Chile & 4.75 & 3.29 \\
\hline PER & Peru & 6.89 & 4.79 \\
\hline HTI & Haiti & 5.02 & 3.63 \\
\hline THA & Thailand & 9.79 & 7.31 \\
\hline BRA & Brazil & 4.60 & 3.65 \\
\hline IDN & Indonesia & 10.70 & 8.55 \\
\hline LAO & Lao PDR & 16.40 & 13.30 \\
\hline PHL & Philippines & 7.49 & 7.08 \\
\hline UKR & Ukraine & 5.75 & 5.53 \\
\hline BOL & Bolivia & 3.73 & 3.65 \\
\hline SLV & El Salvador & 6.14 & 6.09 \\
\hline PRY & Paraguay & 4.55 & 4.65 \\
\hline MWI & Malawi & 2.44 & 2.78 \\
\hline ZMB & Zambia & 2.23 & 2.69 \\
\hline MEX & Mexico & 4.53 & 5.59 \\
\hline HND & Honduras & 5.17 & 6.66 \\
\hline GHA & Ghana & 2.10 & 3.16 \\
\hline RWA & Rwanda & 0.39 & 0.86 \\
\hline COD & Congo, Dem. Rep. & 3.29 & 4.84 \\
\hline BDI & Burundi & 0.23 & 0.89 \\
\hline AGO & Angola & 1.82 & 3.10 \\
\hline MDG & Madagascar & 2.22 & 3.92 \\
\hline GTM & Guatemala & 5.62 & 10.80 \\
\hline SOM & Somalia & 2.42 & 5.65 \\
\hline ETH & Ethiopia & 2.28 & 5.61 \\
\hline TCD & Chad & 1.66 & 4.52 \\
\hline MOZ & Mozambique & 2.11 & 6.09 \\
\hline SDN & Sudan & 3.27 & 9.84 \\
\hline UGA & Uganda & 1.09 & 3.66 \\
\hline TZA & Tanzania & 2.11 & 6.89 \\
\hline SLE & Sierra Leone & 3.78 & 13.75 \\
\hline CMR & Cameroon & 1.95 & 7.14 \\
\hline KAZ & Kazakhstan & 3.36 & 13.70 \\
\hline TGO & Togo & 1.79 & 6.87 \\
\hline ZWE & Zimbabwe & 1.92 & 7.49 \\
\hline BEN & Benin & 1.47 & 6.85 \\
\hline VNM & Vietnam & 3.83 & 18.95 \\
\hline CIV & Cote d'Ivoire & 1.76 & 7.53 \\
\hline TUR & Turkey & 2.48 & 13.65 \\
\hline KEN & Kenya & 0.68 & 4.09 \\
\hline NGA & Nigeria & 0.83 & 5.56 \\
\hline BGD & Bangladesh & 3.97 & 26.98 \\
\hline MAR & Morocco & 2.58 & 17.80 \\
\hline TUN & Tunisia & 0.99 & 6.84 \\
\hline CHN & China & 1.22 & 17.60 \\
\hline IRN & Iran, Islamic Rep. & 0.82 & 6.48 \\
\hline YEM & Yemen, Rep. & 2.73 & 22.20 \\
\hline JOR & Jordan & 0.91 & 8.77 \\
\hline KGZ & Kyrgyz Republic & 2.29 & 21.65 \\
\hline EGY & Egypt, Arab Rep. & 1.12 & 12.11 \\
\hline GIN & Guinea & 1.29 & 13.65 \\
\hline MLI & Mali & 0.41 & 5.57 \\
\hline AZE & Azerbaijan & 2.17 & 25.20 \\
\hline SEN & Senegal & 2.54 & 30.16 \\
\hline IND & India & 2.12 & 31.45 \\
\hline BFA & Burkina Faso & 0.61 & 10.36 \\
\hline NPL & Nepal & 1.98 & 30.73 \\
\hline
\end{tabular}




\begin{tabular}{llcc}
\hline \multirow{2}{*}{$(1)$} & $(2)$ & $\begin{array}{c}\text { Table continued from previous page } \\
(3)\end{array}$ & $\begin{array}{c}(4) \\
\text { ISO Code }\end{array}$ \\
& Country & $\begin{array}{c}\text { \% Couples Living Wife's Parents } \\
\text { mean }\end{array}$ & $\begin{array}{c}\text { \% Couples Living Hund's Parents } \\
\text { mean }\end{array}$ \\
\hline NER & Niger & 0.53 & 10.87 \\
DZA & Algeria & 0.81 & 16.00 \\
PAK & Pakistan & 1.84 & 36.60 \\
UZB & Uzbekistan & 1.22 & 30.00 \\
IRQ & Iraq & 0.88 & 24.70 \\
TKM & Turkmenistan & 1.03 & 30.60 \\
AFG & Afghanistan & 1.17 & 34.70 \\
TJK & Tajikistan & 0.83 & 37.75 \\
\hline \hline
\end{tabular}

Source: Data from Global Data Lab (https://globaldatalab.org/areadata/patrilocal/).

Notes: This table contains the 68 countries included in Figure 1. They have a population greater than

5 million and at least one data point on co-residence with parents between 2000 and 2016. We take the

mean if there are several data points.

Table A.2: Summary Statistics of Explanatory Variables

\begin{tabular}{lcccc}
\hline \hline & $(1)$ & $(2)$ & $(3)$ & $(4)$ \\
& mean & sd & min & max \\
\hline Conditioning Variables & & & & \\
Age (husband) $^{c}$ & 36.46 & $(8.50)$ & 19.00 & 61.00 \\
Number of brothers (husband) $^{c}$ & 2.09 & $(1.40)$ & 0.00 & 8.00 \\
Age oldest living parent $^{c}$ & 65.85 & $(10.28)$ & 42.00 & 98.00 \\
Wife Characteristics $^{c}$ & & & & \\
Age $^{c}$ & 32.83 & $(8.49)$ & 20.00 & 50.00 \\
Low school education $^{a}$ & 0.10 & $(0.30)$ & 0.00 & 1.00 \\
Medium school education $^{a}$ & 0.58 & $(0.49)$ & 0.00 & 1.00 \\
High school education $^{a}$ & 0.32 & $(0.47)$ & 0.00 & 1.00 \\
Kyrgyz $_{\text {Uzbek }}$ & 0.70 & $(0.46)$ & 0.00 & 1.00 \\
Russian $_{\text {Other ethnicities }}$ & 0.16 & $(0.37)$ & 0.00 & 1.00 \\
Residence Characteristics $_{\text {South Kyrgyzstan }}$ & 0.03 & $(0.18)$ & 0.00 & 1.00 \\
Community in urban area $_{\text {Kindergarten in community }}$ & 0.11 & $(0.31)$ & 0.00 & 1.00 \\
Husband Characteristics $^{\text {Low school education (husband) }}{ }^{a}$ & & & & \\
Medium school education (husband) $^{a}$ & 0.57 & $(0.50)$ & 0.00 & 1.00 \\
High school education (husband) $^{a}$ & 0.27 & $(0.45)$ & 0.00 & 1.00 \\
\hline \hline
\end{tabular}

Source: Life in Kyrgyzstan (LIK) Survey, wave 2011, own calculations.

Notes: ${ }^{c}$ denotes continuous variable.

a The provinces of Jalal-Abad, Batken and Osh as well as Osh city belong to the south. The provinces of Issyk-Kul, Naryn, Talas and Chui as well as the capital city Bishkek belong to the north.

${ }^{b}$ Education is defined based on the highest certificate / diploma / degree obtained so far. The categories are: Low education (illiterate, primary, basic), Medium education (secondary general, primary technical), High education (secondary technical, university). 
Table A.3: Non-Parametric Differences in Pre-Marriage Characteristics

\begin{tabular}{|c|c|c|c|c|c|}
\hline & $\begin{array}{c}(1) \\
\text { Treated }\end{array}$ & $\begin{array}{c}(2) \\
\text { Controls }\end{array}$ & $\begin{array}{c}(3) \\
\text { Difference }\end{array}$ & $\begin{array}{l}\text { (4) } \\
\text { S.E. }\end{array}$ & $\begin{array}{c}\text { (5) } \\
\text { T-Stat }\end{array}$ \\
\hline \multicolumn{6}{|l|}{ A. Wife } \\
\hline Age at marriage $^{c}$ & 21.35 & 20.84 & 0.51 & 0.82 & 0.62 \\
\hline Kyrgyz & 0.64 & 0.69 & -0.05 & 0.11 & -0.45 \\
\hline Uzbek & 0.15 & 0.18 & -0.03 & 0.09 & -0.33 \\
\hline Russian & 0.05 & 0.03 & 0.03 & 0.04 & 0.75 \\
\hline Other ethnicity & 0.15 & 0.10 & 0.05 & 0.07 & 0.70 \\
\hline Total number of siblings ${ }^{c}$ & 3.36 & 3.88 & -0.52 & 0.47 & -1.11 \\
\hline Years of education $^{c}$ & 11.00 & 10.97 & 0.03 & 0.49 & 0.06 \\
\hline More than 11 years of education & 0.28 & 0.36 & -0.08 & 0.11 & -0.73 \\
\hline Worked in $\mathrm{t}-1$ if $\mathrm{t}=$ year of marriage & 0.23 & 0.26 & -0.03 & 0.11 & -0.27 \\
\hline Worked in $\mathrm{t}-2$ if $\mathrm{t}=$ year of marriage & 0.10 & 0.23 & -0.13 & 0.10 & -1.30 \\
\hline \multicolumn{6}{|l|}{ B. Husband } \\
\hline Age at marriage $^{c}$ & 25.32 & 25.49 & -0.16 & 1.10 & -0.15 \\
\hline Kyrgyz & 0.64 & 0.69 & -0.05 & 0.11 & -0.45 \\
\hline Uzbek & 0.15 & 0.18 & -0.03 & 0.09 & -0.33 \\
\hline Russian & 0.03 & 0.03 & 0.00 & 0.04 & 0.00 \\
\hline Other ethnicity & 0.18 & 0.10 & 0.08 & 0.08 & 1.00 \\
\hline Total number of siblings ${ }^{c}$ & 3.64 & 3.85 & -0.21 & 0.40 & -0.52 \\
\hline Years of education ${ }^{c}$ & 10.92 & 10.78 & 0.14 & 0.45 & 0.31 \\
\hline More than 11 years of education & 0.31 & 0.28 & 0.03 & 0.11 & 0.27 \\
\hline Worked in $\mathrm{t}-1$ if $\mathrm{t}=$ year of marriage & 0.82 & 0.82 & 0.00 & 0.1 & 0.00 \\
\hline Worked in $\mathrm{t}-2$ if $\mathrm{t}=$ year of marriage & 0.86 & 0.68 & 0.18 & 0.11 & 1.64 \\
\hline
\end{tabular}

Source: Life in Kyrgyzstan (LIK) Survey, wave 2011, own calculations.

Notes: ${ }^{c}$ denotes continuous variable.

Panel A compares pre-marriage characteristics of women married to youngest sons (treated) and not married to youngest sons (control). Panel B compares pre-marriage characteristics of husbands being youngest sons (treated) and not being youngest sons (control). Comparisons are based on matching results, whereby the variable youngest son is used as treatment. The following information are used for balancing: number of brothers of the husband, age of the husband and age of the oldest living parent of the husband. Column (1) (column (2)) provides the average treatment effect of the treated (controls), column (3) their difference. Column (4) provides the standard error and column (5) the t-statistic. Critical values of t-distribution: $t_{\infty, 0.95}=1.645, t_{\infty, 0.975}=1.96$, $t_{\infty, 0.995}=2.576$. 
Table A.4: Number Of Children Up To Age Five

\begin{tabular}{lc}
\hline \hline & $(1)$ \\
\hline Married to youngest son & $0.117^{* *}$ \\
& $(0.059)$ \\
Age husband & $-.040^{* * *}$ \\
& $(0.004)$ \\
No. of brothers (husband) & $0.039^{* *}$ \\
& $(0.02)$ \\
Age oldest living parent (husband) & -.0006 \\
& $(0.004)$ \\
Const. & $2.201^{* * *}$ \\
& $(0.154)$ \\
Obs. & 1,048 \\
\hline \hline
\end{tabular}

Source: Life in Kyrgyzstan (LIK) Survey, wave 2011, own calculations.

Notes: Standard errors in parentheses. ${ }^{*} p<0.1$, ${ }^{* *} p<0.05,{ }^{* * *} p<0.01$. 
Table A.5: Estimation Results: Number Of Children Up To Age Five

\begin{tabular}{|c|c|c|c|c|c|}
\hline & $(1)$ & $(2)$ & $(3)$ & $(4)$ & $(5)$ \\
\hline \multicolumn{6}{|c|}{$\begin{array}{l}\text { A. OLS Estimation Results } \\
\text { (Co-residence exogenous) }\end{array}$} \\
\hline Co-residence & $\begin{array}{c}0.334^{* * *} \\
(0.051)\end{array}$ & $\begin{array}{l}-.046 \\
(0.057)\end{array}$ & $\begin{array}{l}-.031 \\
(0.056)\end{array}$ & $\begin{array}{l}-.024 \\
(0.057)\end{array}$ & $\begin{array}{l}-.029 \\
(0.057)\end{array}$ \\
\hline \multicolumn{6}{|c|}{$\begin{array}{l}\text { B. Two-stage Least-Squares Estimation Results } \\
\text { (Co-residence endogenous) }\end{array}$} \\
\hline \multicolumn{6}{|l|}{ Second Stage } \\
\hline Co-residence & $\begin{array}{c}0.596^{* * *} \\
(0.171)\end{array}$ & $\begin{array}{l}0.573^{*} \\
(0.307)\end{array}$ & $\begin{array}{c}0.579^{* *} \\
(0.282)\end{array}$ & $\begin{array}{c}0.557^{* *} \\
(0.272)\end{array}$ & $\begin{array}{c}0.552^{* *} \\
(0.275)\end{array}$ \\
\hline Observations & 1,048 & 1,048 & 1,048 & 1,048 & 1,048 \\
\hline Conditioning Variables & & $\checkmark$ & $\checkmark$ & $\checkmark$ & $\checkmark$ \\
\hline Wife Characteristics & & & $\checkmark$ & $\checkmark$ & $\checkmark$ \\
\hline Residence Characteristics & & & & $\checkmark$ & $\checkmark$ \\
\hline Husband Characteristics & & & & & $\checkmark$ \\
\hline
\end{tabular}

Source: Life in Kyrgyzstan (LIK) Survey, wave 2011, own calculations.

Notes: Standard errors in parentheses. ${ }^{*} p<0.1,{ }^{* *} p<0.05,{ }^{* * *} p<0.01$.

Conditioning variables: age of the husband, number of brothers of the husband, age of the oldest living parent of the husband.

Wife characteristics: age, educational attainment, ethnicity.

Residence characteristics: community is located in south Kyrgyzstan, community is urban, availability of kindergarten.

Husband characteristic: educational attainment. 
Table A.6: OLS Estimation Results: Female Labour Force Participation

\begin{tabular}{|c|c|c|c|c|c|}
\hline & $(1)$ & $(2)$ & $(3)$ & $(4)$ & $(5)$ \\
\hline Co-Residence & $\begin{array}{c}-.168^{* * *} \\
(0.03)\end{array}$ & $\begin{array}{l}-.057 \\
(0.036)\end{array}$ & $\begin{array}{l}-.023 \\
(0.037)\end{array}$ & $\begin{array}{l}-.049 \\
(0.037)\end{array}$ & $\begin{array}{l}-.050 \\
(0.037)\end{array}$ \\
\hline Age Husband & & $\begin{array}{c}0.012^{* * *} \\
(0.003)\end{array}$ & $\begin{array}{l}-.003 \\
(0.005)\end{array}$ & $\begin{array}{l}-.004 \\
(0.005)\end{array}$ & $\begin{array}{l}-.004 \\
(0.005)\end{array}$ \\
\hline No. of brothers (husband) & & $\begin{array}{c}0.003 \\
(0.011)\end{array}$ & $\begin{array}{c}0.005 \\
(0.011)\end{array}$ & $\begin{array}{c}0.002 \\
(0.011)\end{array}$ & $\begin{array}{c}0.002 \\
(0.011)\end{array}$ \\
\hline Age oldest living parent (husband) & & $\begin{array}{l}-.0002 \\
(0.002)\end{array}$ & $\begin{array}{l}-.0007 \\
(0.002)\end{array}$ & $\begin{array}{c}-.00002 \\
(0.002)\end{array}$ & $\begin{array}{c}0.00007 \\
(0.002)\end{array}$ \\
\hline Age Women & & & $\begin{array}{c}0.047^{* * *} \\
(0.016)\end{array}$ & $\begin{array}{c}0.045^{* * *} \\
(0.016)\end{array}$ & $\begin{array}{c}0.045^{* * *} \\
(0.016)\end{array}$ \\
\hline Age Women ${ }^{2}$ & & & $\begin{array}{c}-.0004^{* *} \\
(0.0002)\end{array}$ & $\begin{array}{l}-.0004^{*} \\
(0.0002)\end{array}$ & $\begin{array}{c}-.0004^{*} \\
(0.0002)\end{array}$ \\
\hline Medium school education & & & $\begin{array}{c}0.177^{* * *} \\
(0.054)\end{array}$ & $\begin{array}{c}0.164^{* * *} \\
(0.054)\end{array}$ & $\begin{array}{c}0.178^{* * *} \\
(0.056)\end{array}$ \\
\hline Higher school education & & & $\begin{array}{c}0.275^{* * *} \\
(0.058)\end{array}$ & $\begin{array}{c}0.291^{* * *} \\
(0.059)\end{array}$ & $\begin{array}{c}0.301^{* * *} \\
(0.061)\end{array}$ \\
\hline Kyrgyz & & & $\begin{array}{c}0.068 \\
(0.084)\end{array}$ & $\begin{array}{l}-.002 \\
(0.086)\end{array}$ & $\begin{array}{c}-.001 \\
(0.086)\end{array}$ \\
\hline Uzbek & & & $\begin{array}{c}0.106 \\
(0.091)\end{array}$ & $\begin{array}{c}0.033 \\
(0.095)\end{array}$ & $\begin{array}{c}0.032 \\
(0.096)\end{array}$ \\
\hline Other ethnicities & & & $\begin{array}{l}-.059 \\
(0.093)\end{array}$ & $\begin{array}{l}-.119 \\
(0.094)\end{array}$ & $\begin{array}{l}-.121 \\
(0.094)\end{array}$ \\
\hline Oblast in south & & & & $\begin{array}{c}0.047 \\
(0.034)\end{array}$ & $\begin{array}{c}0.045 \\
(0.034)\end{array}$ \\
\hline Community in urban area & & & & $\begin{array}{c}-.143^{* * *} \\
(0.039)\end{array}$ & $\begin{array}{c}-.146^{* * *} \\
(0.039)\end{array}$ \\
\hline Kindergarten in community & & & & $\begin{array}{c}0.055 \\
(0.034)\end{array}$ & $\begin{array}{c}0.055 \\
(0.034)\end{array}$ \\
\hline Medium school education (husband) & & & & & $\begin{array}{l}-.042 \\
(0.049)\end{array}$ \\
\hline Higher school education (husband) & & & & & $\begin{array}{l}-.029 \\
(0.055)\end{array}$ \\
\hline Const. & $\begin{array}{c}0.558^{* * *} \\
(0.021)\end{array}$ & $\begin{array}{c}0.07 \\
(0.109)\end{array}$ & $\begin{array}{c}-.643^{* *} \\
(0.279)\end{array}$ & $\begin{array}{c}-.551^{* *} \\
(0.278)\end{array}$ & $\begin{array}{c}-.530^{*} \\
(0.28)\end{array}$ \\
\hline Obs. & 1048 & 1048 & 1048 & 1048 & 1048 \\
\hline
\end{tabular}

Source: Life in Kyrgyzstan (LIK) Survey, wave 2011, own calculations.

Notes: Standard errors in parentheses. ${ }^{*} p<0.1,{ }^{* *} p<0.05,{ }^{* * *} p<0.01$. 
Table A.7: Two-stage Least-Squares Estimation Results: Co-Residence (First Stage)

\begin{tabular}{|c|c|c|c|c|c|}
\hline & $(1)$ & $(2)$ & $(3)$ & $(4)$ & $(5)$ \\
\hline Youngest Son & $\begin{array}{c}0.316^{* * *} \\
(0.031)\end{array}$ & $\begin{array}{c}0.204^{* * *} \\
(0.032)\end{array}$ & $\begin{array}{c}0.21^{* * *} \\
(0.031)\end{array}$ & $\begin{array}{c}0.216^{* * *} \\
(0.03)\end{array}$ & $\begin{array}{c}0.214^{* * *} \\
(0.03)\end{array}$ \\
\hline Age Husband & & $\begin{array}{c}-.033^{* * *} \\
(0.002)\end{array}$ & $\begin{array}{c}-.014^{* * *} \\
(0.004)\end{array}$ & $\begin{array}{c}-.013^{* * *} \\
(0.004)\end{array}$ & $\begin{array}{c}-.013^{* * *} \\
(0.004)\end{array}$ \\
\hline No. of brothers (husband) & & $\begin{array}{c}-.006 \\
(0.011)\end{array}$ & $\begin{array}{l}-.006 \\
(0.01)\end{array}$ & $\begin{array}{l}-.007 \\
(0.01)\end{array}$ & $\begin{array}{l}-.009 \\
(0.01)\end{array}$ \\
\hline Age oldest living parent (husband) & & $\begin{array}{c}0.004^{* *} \\
(0.002)\end{array}$ & $\begin{array}{c}0.004^{* *} \\
(0.002)\end{array}$ & $\begin{array}{c}0.004^{* *} \\
(0.002)\end{array}$ & $\begin{array}{c}0.005^{* *} \\
(0.002)\end{array}$ \\
\hline Age Women & & & $\begin{array}{c}-.104^{* * *} \\
(0.013)\end{array}$ & $\begin{array}{c}-.102^{* * *} \\
(0.013)\end{array}$ & $\begin{array}{c}-.103^{* * *} \\
(0.013)\end{array}$ \\
\hline Age Women ${ }^{2}$ & & & $\begin{array}{c}0.001^{* * *} \\
(0.0002)\end{array}$ & $\begin{array}{c}0.001^{* * *} \\
(0.0002)\end{array}$ & $\begin{array}{c}0.001^{* * *} \\
(0.0002)\end{array}$ \\
\hline Medium school education & & & $\begin{array}{c}0.073 \\
(0.045)\end{array}$ & $\begin{array}{c}0.055 \\
(0.044)\end{array}$ & $\begin{array}{l}0.077^{*} \\
(0.046)\end{array}$ \\
\hline Higher school education & & & $\begin{array}{l}0.086^{*} \\
(0.048)\end{array}$ & $\begin{array}{c}0.098^{* *} \\
(0.048)\end{array}$ & $\begin{array}{c}0.13^{* * *} \\
(0.05)\end{array}$ \\
\hline Kyrgyz & & & $\begin{array}{l}0.081 \\
(0.07)\end{array}$ & $\begin{array}{l}-.018 \\
(0.071)\end{array}$ & $\begin{array}{l}-.025 \\
(0.071)\end{array}$ \\
\hline Uzbek & & & $\begin{array}{l}0.143^{*} \\
(0.075)\end{array}$ & $\begin{array}{c}0.007 \\
(0.078)\end{array}$ & $\begin{array}{l}-.009 \\
(0.079)\end{array}$ \\
\hline Other ethnicities & & & $\begin{array}{l}0.134^{*} \\
(0.078)\end{array}$ & $\begin{array}{l}0.068 \\
(0.077)\end{array}$ & $\begin{array}{c}0.055 \\
(0.077)\end{array}$ \\
\hline Oblast in south & & & & $\begin{array}{c}0.12^{* * *} \\
(0.028)\end{array}$ & $\begin{array}{c}0.117^{* * *} \\
(0.028)\end{array}$ \\
\hline Community in urban area & & & & $\begin{array}{c}-.116^{* * *} \\
(0.032)\end{array}$ & $\begin{array}{c}-.112^{* * *} \\
(0.032)\end{array}$ \\
\hline Kindergarten in community & & & & $\begin{array}{l}0.047^{*} \\
(0.028)\end{array}$ & $\begin{array}{l}0.051^{*} \\
(0.028)\end{array}$ \\
\hline Medium school education (husband) & & & & & $\begin{array}{l}-.058 \\
(0.04)\end{array}$ \\
\hline Higher school education (husband) & & & & & $\begin{array}{c}-.097^{* *} \\
(0.045)\end{array}$ \\
\hline Const. & $\begin{array}{c}0.368^{* * *} \\
(0.018)\end{array}$ & $\begin{array}{c}1.358^{* * *} \\
(0.082)\end{array}$ & $\begin{array}{c}2.477^{* * *} \\
(0.219)\end{array}$ & $\begin{array}{c}2.465^{* * *} \\
(0.216)\end{array}$ & $\begin{array}{c}2.506^{* * *} \\
(0.217)\end{array}$ \\
\hline Obs. & 1048 & 1048 & 1048 & 1048 & 1048 \\
\hline
\end{tabular}

Source: Life in Kyrgyzstan (LIK) Survey, wave 2011, own calculations.

Notes: Standard errors in parentheses. ${ }^{*} p<0.1,{ }^{* *} p<0.05,{ }^{* * *} p<0.01$. 
Table A.8: Two-stage Least-Squares Estimation Results: Labour Force Participation (Second Stage)

\begin{tabular}{|c|c|c|c|c|c|}
\hline & $(1)$ & $(2)$ & $(3)$ & $(4)$ & $(5)$ \\
\hline Co-Residence & $\begin{array}{l}.196^{*} \\
(0.101)\end{array}$ & $\begin{array}{l}-.084 \\
(0.185)\end{array}$ & $\begin{array}{l}-.106 \\
(0.175)\end{array}$ & $\begin{array}{l}-.097 \\
(0.169)\end{array}$ & $\begin{array}{l}-.102 \\
(0.171)\end{array}$ \\
\hline Age Husband & & $\begin{array}{c}0.011 \\
(0.008)\end{array}$ & $\begin{array}{l}-.005 \\
(0.006)\end{array}$ & $\begin{array}{l}-.005 \\
(0.006)\end{array}$ & $\begin{array}{l}-.005 \\
(0.006)\end{array}$ \\
\hline No. of brothers (husband) & & $\begin{array}{c}0.002 \\
(0.013)\end{array}$ & $\begin{array}{c}0.002 \\
(0.013)\end{array}$ & $\begin{array}{l}0.0005 \\
(0.013)\end{array}$ & $\begin{array}{l}-.0002 \\
(0.013)\end{array}$ \\
\hline Age oldest living parent (husband) & & $\begin{array}{c}0.00002 \\
(0.003)\end{array}$ & $\begin{array}{l}0.0001 \\
(0.003)\end{array}$ & $\begin{array}{l}0.0005 \\
(0.003)\end{array}$ & $\begin{array}{l}0.0006 \\
(0.003)\end{array}$ \\
\hline Age Women & & & $\begin{array}{c}0.039 \\
(0.024)\end{array}$ & $\begin{array}{c}0.04^{*} \\
(0.023)\end{array}$ & $\begin{array}{l}0.039^{*} \\
(0.023)\end{array}$ \\
\hline Age Women ${ }^{2}$ & & & $\begin{array}{l}-.0003 \\
(0.0003)\end{array}$ & $\begin{array}{l}-.0004 \\
(0.0003)\end{array}$ & $\begin{array}{l}-.0004 \\
(0.0003)\end{array}$ \\
\hline Medium school education & & & $\begin{array}{c}0.183^{* * *} \\
(0.056)\end{array}$ & $\begin{array}{c}0.167^{* * *} \\
(0.055)\end{array}$ & $\begin{array}{c}0.183^{* * *} \\
(0.058)\end{array}$ \\
\hline Higher school education & & & $\begin{array}{c}0.283^{* * *} \\
(0.06)\end{array}$ & $\begin{array}{c}0.296^{* * *} \\
(0.061)\end{array}$ & $\begin{array}{c}0.309^{* * *} \\
(0.066)\end{array}$ \\
\hline Kyrgyz & & & $\begin{array}{c}0.071 \\
(0.084)\end{array}$ & $\begin{array}{l}-.005 \\
(0.086)\end{array}$ & $\begin{array}{c}-.005 \\
(0.086)\end{array}$ \\
\hline Uzbek & & & $\begin{array}{c}0.114 \\
(0.092)\end{array}$ & $\begin{array}{c}0.031 \\
(0.095)\end{array}$ & $\begin{array}{c}0.029 \\
(0.095)\end{array}$ \\
\hline Other ethnicities & & & $\begin{array}{l}-.051 \\
(0.094)\end{array}$ & $\begin{array}{l}-.118 \\
(0.093)\end{array}$ & $\begin{array}{l}-.120 \\
(0.093)\end{array}$ \\
\hline Oblast in south & & & & $\begin{array}{c}0.052 \\
(0.038)\end{array}$ & $\begin{array}{c}0.051 \\
(0.038)\end{array}$ \\
\hline Community in urban area & & & & $\begin{array}{c}-.149^{* * *} \\
(0.043)\end{array}$ & $\begin{array}{c}-.152^{* * *} \\
(0.044)\end{array}$ \\
\hline Kindergarten in community & & & & $\begin{array}{c}0.057 \\
(0.035)\end{array}$ & $\begin{array}{c}0.058 \\
(0.035)\end{array}$ \\
\hline Medium school education (husband) & & & & & $\begin{array}{l}-.045 \\
(0.049)\end{array}$ \\
\hline Higher school education (husband) & & & & & $\begin{array}{l}-.035 \\
(0.057)\end{array}$ \\
\hline Const. & $\begin{array}{c}0.571^{* * *} \\
(0.051)\end{array}$ & $\begin{array}{c}0.106 \\
(0.267)\end{array}$ & $\begin{array}{l}-.437 \\
(0.508)\end{array}$ & $\begin{array}{l}-.431 \\
(0.493)\end{array}$ & $\begin{array}{l}-.398 \\
(0.504)\end{array}$ \\
\hline Obs. & 1048 & 1048 & 1048 & 1048 & 1048 \\
\hline
\end{tabular}

Source: Life in Kyrgyzstan (LIK) Survey, wave 2011, own calculations.

Notes: Standard errors in parentheses. ${ }^{*} p<0.1,{ }^{* *} p<0.05,{ }^{* * *} p<0.01$. 
Table A.9: Tobit Estimation Results: Working Hours

\begin{tabular}{|c|c|c|c|c|c|}
\hline & $(1)$ & $(2)$ & $(3)$ & $(4)$ & $(5)$ \\
\hline Co-residence & $\begin{array}{c}-14.241^{* * *} \\
(2.672)\end{array}$ & $\begin{array}{l}-4.388 \\
(3.131)\end{array}$ & $\begin{array}{l}-1.264 \\
(3.179)\end{array}$ & $\begin{array}{l}-2.700 \\
(3.244)\end{array}$ & $\begin{array}{l}-2.820 \\
(3.254)\end{array}$ \\
\hline Age (husband) & & $\begin{array}{c}1.118^{* * *} \\
(0.258)\end{array}$ & $\begin{array}{l}-.014 \\
(0.467)\end{array}$ & $\begin{array}{l}-.048 \\
(0.468)\end{array}$ & $\begin{array}{l}-.040 \\
(0.469)\end{array}$ \\
\hline No. of brothers (husband) & & $\begin{array}{c}0.29 \\
(0.964)\end{array}$ & $\begin{array}{l}0.443 \\
(0.97)\end{array}$ & $\begin{array}{c}0.355 \\
(0.972)\end{array}$ & $\begin{array}{c}0.345 \\
(0.974)\end{array}$ \\
\hline Age oldest living parent (husband) & & $\begin{array}{l}-.082 \\
(0.195)\end{array}$ & $\begin{array}{l}-.114 \\
(0.194)\end{array}$ & $\begin{array}{l}-.083 \\
(0.195)\end{array}$ & $\begin{array}{l}-.081 \\
(0.195)\end{array}$ \\
\hline Age women & & & $\begin{array}{c}5.102^{* * *} \\
(1.439)\end{array}$ & $\begin{array}{c}5.021^{* * *} \\
(1.442)\end{array}$ & $\begin{array}{c}5.024^{* * *} \\
(1.445)\end{array}$ \\
\hline Age women ${ }^{2}$ & & & $\begin{array}{c}-.056^{* * *} \\
(0.019)\end{array}$ & $\begin{array}{c}-.055^{* * *} \\
(0.02)\end{array}$ & $\begin{array}{c}-.055^{* * *} \\
(0.02)\end{array}$ \\
\hline Medium education & & & $\begin{array}{c}14.432^{* * *} \\
(5.202)\end{array}$ & $\begin{array}{c}13.605^{* * *} \\
(5.228)\end{array}$ & $\begin{array}{c}14.974^{* * *} \\
(5.477)\end{array}$ \\
\hline High education & & & $\begin{array}{c}22.755^{* * *} \\
(5.512)\end{array}$ & $\begin{array}{c}23.155^{* * *} \\
(5.583)\end{array}$ & $\begin{array}{c}23.992^{* * *} \\
(5.857)\end{array}$ \\
\hline Kyrgyz & & & $\begin{array}{c}1.859 \\
(7.318)\end{array}$ & $\begin{array}{l}-1.544 \\
(7.540)\end{array}$ & $\begin{array}{l}-1.339 \\
(7.553)\end{array}$ \\
\hline Uzbek & & & $\begin{array}{c}7.431 \\
(7.893)\end{array}$ & $\begin{array}{c}3.458 \\
(8.360)\end{array}$ & $\begin{array}{c}3.571 \\
(8.406)\end{array}$ \\
\hline Other ethnicities & & & $\begin{array}{l}-9.901 \\
(8.297)\end{array}$ & $\begin{array}{c}-12.711 \\
(8.420)\end{array}$ & $\begin{array}{c}-12.659 \\
(8.439)\end{array}$ \\
\hline South Kyrgyzstan & & & & $\begin{array}{c}3.119 \\
(2.979)\end{array}$ & $\begin{array}{c}2.984 \\
(2.981)\end{array}$ \\
\hline Community in urban area & & & & $\begin{array}{c}-6.473^{*} \\
(3.448)\end{array}$ & $\begin{array}{c}-6.881^{* *} \\
(3.486)\end{array}$ \\
\hline Kindergarten in community & & & & $\begin{array}{l}4.056 \\
(3.013)\end{array}$ & $\begin{array}{c}3.977 \\
(3.018)\end{array}$ \\
\hline Medium education (husband) & & & & & $\begin{array}{l}-3.956 \\
(4.362)\end{array}$ \\
\hline High education (husband) & & & & & $\begin{array}{l}-1.861 \\
(4.861)\end{array}$ \\
\hline Const. & $\begin{array}{c}6.661^{* * *} \\
(1.871)\end{array}$ & $\begin{array}{c}-34.123^{* * *} \\
(9.708)\end{array}$ & $\begin{array}{c}-113.060^{* * *} \\
(25.309)\end{array}$ & $\begin{array}{c}-110.261^{* * *} \\
(25.499)\end{array}$ & $\begin{array}{c}-108.637^{* * *} \\
(25.642)\end{array}$ \\
\hline Obs. & 1,048 & 1,048 & 1,048 & 1,048 & 1,048 \\
\hline
\end{tabular}

Source: Life in Kyrgyzstan (LIK) Survey, wave 2011, own calculations.

Notes: Standard errors in parentheses. ${ }^{*} p<0.1,{ }^{* *} p<0.05,{ }^{* * *} p<0.01$. 
Table A.10: IV Tobit Estimation Results: Working Hours (Second Stage)

\begin{tabular}{|c|c|c|c|c|c|}
\hline & $(1)$ & $(2)$ & $(3)$ & $(4)$ & $(5)$ \\
\hline Co-Residence & $\begin{array}{c}-19.731^{* *} \\
(8.874)\end{array}$ & $\begin{array}{l}-12.161 \\
(16.120)\end{array}$ & $\begin{array}{l}-15.299 \\
(15.519)\end{array}$ & $\begin{array}{l}-14.115 \\
(15.041)\end{array}$ & $\begin{array}{l}-14.417 \\
(15.212)\end{array}$ \\
\hline Age Husband & & $\begin{array}{c}0.816 \\
(0.666)\end{array}$ & $\begin{array}{c}-.279 \\
(0.552)\end{array}$ & $\begin{array}{l}-.260 \\
(0.545)\end{array}$ & $\begin{array}{l}-.251 \\
(0.543)\end{array}$ \\
\hline No. of brothers (husband) & & $\begin{array}{c}0.003 \\
(1.130)\end{array}$ & $\begin{array}{c}-.067 \\
(1.124)\end{array}$ & $\begin{array}{c}-.077 \\
(1.125)\end{array}$ & $\begin{array}{l}-.114 \\
(1.143)\end{array}$ \\
\hline Age oldest living parent (husband) & & $\begin{array}{c}-.009 \\
(0.245)\end{array}$ & $\begin{array}{c}0.023 \\
(0.246)\end{array}$ & $\begin{array}{c}0.031 \\
(0.245)\end{array}$ & $\begin{array}{c}0.039 \\
(0.249)\end{array}$ \\
\hline Age Women & & & $\begin{array}{l}3.660^{*} \\
(2.127)\end{array}$ & $\begin{array}{l}3.867^{*} \\
(2.071)\end{array}$ & $\begin{array}{l}3.833^{*} \\
(2.103)\end{array}$ \\
\hline Age Women ${ }^{2}$ & & & $\begin{array}{l}-.039 \\
(0.027)\end{array}$ & $\begin{array}{l}-.042 \\
(0.026)\end{array}$ & $\begin{array}{l}-.042 \\
(0.026)\end{array}$ \\
\hline Medium school education & & & $\begin{array}{c}15.635^{* * *} \\
(5.407)\end{array}$ & $\begin{array}{c}14.390^{* * *} \\
(5.353)\end{array}$ & $\begin{array}{c}16.047^{* * *} \\
(5.678)\end{array}$ \\
\hline Higher school education & & & $\begin{array}{c}24.170^{* * *} \\
(5.771)\end{array}$ & $\begin{array}{c}24.441^{* * *} \\
(5.857)\end{array}$ & $\begin{array}{c}25.709^{* * * *} \\
(6.293)\end{array}$ \\
\hline Kyrgyz & & & $\begin{array}{c}2.332 \\
(7.402)\end{array}$ & $\begin{array}{l}-2.251 \\
(7.637)\end{array}$ & $\begin{array}{l}-2.141 \\
(7.666)\end{array}$ \\
\hline Uzbek & & & $\begin{array}{c}8.744 \\
(8.092)\end{array}$ & $\begin{array}{c}3.063 \\
(8.423)\end{array}$ & $\begin{array}{c}2.963 \\
(8.491)\end{array}$ \\
\hline Other ethnicities & & & $\begin{array}{l}-8.631 \\
(8.479)\end{array}$ & $\begin{array}{c}-12.422 \\
(8.473)\end{array}$ & $\begin{array}{c}-12.511 \\
(8.487)\end{array}$ \\
\hline Oblast in south & & & & $\begin{array}{c}4.392 \\
(3.416)\end{array}$ & $\begin{array}{c}4.239 \\
(3.403)\end{array}$ \\
\hline Community in urban area & & & & $\begin{array}{c}-7.802^{* *} \\
(3.870)\end{array}$ & $\begin{array}{c}-8.175^{* *} \\
(3.881)\end{array}$ \\
\hline Kindergarten in community & & & & $\begin{array}{c}4.621 \\
(3.117)\end{array}$ & $\begin{array}{c}4.597 \\
(3.140)\end{array}$ \\
\hline Medium school education (husband) & & & & & $\begin{array}{l}-4.694 \\
(4.490)\end{array}$ \\
\hline Higher school education (husband) & & & & & $\begin{array}{l}-3.104 \\
(5.145)\end{array}$ \\
\hline Const. & $\begin{array}{c}9.289^{* *} \\
(4.442)\end{array}$ & $\begin{array}{l}-23.599 \\
(23.480)\end{array}$ & $\begin{array}{c}-78.264^{*} \\
(45.350)\end{array}$ & $\begin{array}{c}-82.056^{*} \\
(44.314)\end{array}$ & $\begin{array}{c}-79.463^{*} \\
(45.292)\end{array}$ \\
\hline Obs. & 1048 & 1048 & 1048 & 1048 & 1048 \\
\hline
\end{tabular}

Source: Life in Kyrgyzstan (LIK) Survey, wave 2011, own calculations.

Notes: Standard errors in parentheses. ${ }^{*} p<0.1,{ }^{* *} p<0.05,{ }^{* * *} p<0.01$. 
Table A.11: Summary Statistics of Variables used in Channel Analysis

\begin{tabular}{lccccc}
\hline \hline & $(1)$ & $(2)$ & $(3)$ & $(4)$ & $(5)$ \\
& $\mathrm{n}$ & mean & sd & $\min$ & $\max$ \\
\hline Woman & & & & & \\
$\quad$ Elder care time (in Hours) & 1,048 & 0.13 & $(0.47)$ & 0 & 6.5 \\
Child care time (in Hours) & 1,048 & 1.76 & $(1.97)$ & 0 & 12 \\
$\quad$ Housekeeping time (in Hours) & 1,048 & 5.38 & $(2.69)$ & 0 & 14 \\
Parents or in-laws & & & & & 60.00 \\
$\quad$ Income parents (in 1000 Som) & 501 & 4.17 & $(4.84)$ & 0 & 1.52 \\
$\quad$ Gender attitudes (std.) & 490 & -0.05 & $(0.98)$ & -2.86 & \\
\hline \hline
\end{tabular}

Source: Life in Kyrgyzstan (LIK) Survey, wave 2011, own calculations.

Notes: Summary statistics of parents or in-laws are restricted to only co-residing women.

Table A.12: Gender Attitude Items

\begin{tabular}{lc}
\hline \hline $\begin{array}{l}\text { Gender Attitude Items } \\
\text { (Scale 1-4) }\end{array}$ & $\begin{array}{c}\text { Liberal/ } \\
\text { Traditional }\end{array}$ \\
\hline I1: Important decisions should be made by the husband rather than the wife & $\mathrm{T}$ \\
I2: A man's job is to earn money; a woman's job is to look after the home and family & $\mathrm{T}$ \\
I3: A women is really fulfilled only when she becomes a mother & $\mathrm{T}$ \\
I4: A working women can establish just as warm and secure of relationship with her & \\
children as a mother who does not work & $\mathrm{L}$ \\
I5: A husband's career should be more important to the wife than her own & $\mathrm{T}$ \\
I6: A university education is more important for a boy than for a girl & $\mathrm{T}$ \\
I7: Both the husband and the wife should contribute to the household income & $\mathrm{L}$ \\
\hline \hline
\end{tabular}

Source: Life in Kyrgyzstan (LiK) Individual Questionnaire 2011.

Notes: Items marked with $\mathrm{T} / \mathrm{L}$ refer to items which are categorized as traditional (T) or liberal (L), meaning the respondent has a rather traditional/liberal attitude towards the role of females in the society. 